\title{
Modulation by surroundings of the antibacterial efficiency of silver in water environments
}

Adeline Marguier ${ }^{1,2}$, Sophie Lakard ${ }^{4}$, Charline Soraru ${ }^{1,2}$, Maxime Delmée ${ }^{5}$, Jean-Marc Le Meins ${ }^{1,2}$, Vincent Roucoules ${ }^{1,2}$, David Ruch ${ }^{5}$, Loic Vidal ${ }^{1,2}$, Lydie Ploux ${ }^{1,2,3 *}$

${ }^{1}$ Université de Haute-Alsace, CNRS, IS2M UMR 7361, F-68100 Mulhouse, France

${ }^{2}$ Université de Strasbourg, France

${ }^{3}$ Université de Strasbourg, INSERM, BIOMAT U1121, F-67000 Strasbourg, France

${ }^{4}$ Université de Franche-Comté, CNRS, UTINAM 6213, F-25000 Besançon, France

${ }^{5}$ Luxembourg Institute of Science and Technology (LIST), L-4362 Esch-sur-Alzette, Luxembourg

* Corresponding author: Dr Lydie Ploux

ploux@unistra.fr

+33(0)368855479

\section{Acknowledgements}

The authors thank the Région Alsace, the French National Center for Scientific Research (CNRS) and the Luxembourg National Research Fund (FNR) for their financial supports. The authors from LIST were funded through the $\mathrm{HABaC}$ project (FNR CORE project). They also thank Hélène Thai and Anaïs Maccorin for their assistance in the microbiological assays. They acknowledge Julien Bardon for English revision of the manuscript. 


\section{Abstract}

Silver is a usual antibacterial agent acting in water solutions. However, quantitative data fail to anticipate the silver availability for interactions with bacterial cells and the resulting fluctuations of the inhibitory and bactericidal concentrations according to silver amount and chemical composition of the liquid environment. We investigated whether and how three different biological media modify silver ions $\left(\mathrm{Ag}^{+}\right)$and nanoparticles (AgNPs), and alter their antibacterial performances against Escherichia coli K12. The predominant silver species highly differed in terms of nature and quantity according to the medium. Bioavailability was reduced to a few percent of the initial $\mathrm{Ag}^{+}$amount in physiological serum ( $\mathrm{NaCl}$ ) and lysogeny-broth (LB), while it was higher than $67 \%$ in minimal phosphate medium (M63G). To reach similar antibacterial performances, $\mathrm{Ag}^{+}$concentrations were 100 times lower in M63G than in the other media. Even with a silver concentration of $10^{-1} \mathrm{M}, 53 \%$ of the bacterial cells living after $3 \mathrm{~h}$ in LB were undamaged and revealed normal metabolic activity, while the cells were almost completely eliminated in M63G. Effects of AgNPs were also strongly but differently modulated by the medium's components. AgNPs revealed higher antibacterial effect than $\mathrm{Ag}^{+}$in $\mathrm{NaCl}$ and M63G with similar silver content, thus providing an argument to assert that AgNPs act through a combination of release of $\mathrm{Ag}^{+}$and intake of $\mathrm{AgNPs}$. Our results finally provide guidelines about the $\mathrm{Ag}^{+}$dose that must be released from coatings to reach efficient performances according to the surrounding medium and the framework of the study.

\section{Keywords}

Silver ions, silver nanoparticles, antibacterial action, effect of the medium, Escherichia coli 


\section{Introduction}

Silver is used as an antibacterial agent since ancient times(Silver et al. 2006). Today, aside from a common use in wound care especially to treat burn victims, silver is often proposed as the active substance of antimicrobial materials (Knetsch and Koole 2011; MacGregor and group 2012). It is the active substance which is the most often selected (20\% of the publications in the period from July 2016 to June 2017) to provide antibacterial i.e. inhibitory or bactericidal properties to materials and material coatings (Bibliographic research in the PubMed database; date: 06/28/2017; keyword: antibacterial coating). In this frame, bioactivity is usually expected to be induced by silver ions which are released either directly from the material or from immobilized nanoparticles, due to the particles oxidation and dissolution (Le Ouay and Stellacci 2015; Liu et al. 2010). Silver nanoparticles are also considered by some authors to produce a high level of direct bioactivity (Kędziora et al. 2018) even if immobilized (Agnihotri et al. 2013), but this is still controversial (Ivask et al. 2014a).

Silver ions and nanoparticles have the same targets in the bacterial cell i.e. cell wall and membranes, enzymes and other proteins, or phosphorus-containing molecules such as DNA (Durán et al. 2016; Slavin et al. 2017). Their mechanisms of action are also similar to a large extent (Kędziora et al. 2018) (Fig 1A). Indeed, even for nanoparticles, there is broad agreement that the dominant mechanism is due to silver ions released by oxidation and dissolution of the nanoparticles (Marchioni et al. 2018a). Then, due to positive electrostatic charge, silver ions can interact with bacterial cell wall and membrane, especially with phosphate groups in phospholipids. This leads to membrane's disruption with creation of pits and results in a leakage of potassium ions and subsequent cell death. In addition, silver ions can enter into bacterial cells through transmembrane proteins and other uptake systems and disturb cellular machinery by binding thiol groups of proteins and nucleic acids inside the cell(Feng et al. 2000). Proteins are thus inactivated and DNA is unable to replicate. An additional mechanism of action has been proposed for silver nanoparticles that may indirectly affect bacterial cells by favoring the production of reactive oxygen species (ROS) and a consequential oxidative stress (Durán et al. 2016; Ivask et al. 2014a; Long et al. 2017).

Besides, the toxicity of silver is still discussed, even though the ionic form is often considered to be almost harmless for human health, and there are ever more concerns regarding its impact on the environment (Fraser et al. 2018; Gliga et al. 2018; Ip et al. 2006; Jakobsen et al. 2011; Marchioni et al. 2018b; Ratte 1999; Silver et al. 2006; Sütterlin et al. 2017). Therefore, in order to reduce the threats related to the use of inappropriate amounts of silver, the exact dose to be used in specific conditions for reaching sufficient bioactivity is a crucial issue. 
The fraction of silver really available for bioactivity depends on the surrounding environment. If silver is initially stored as nanoparticles, their oxidation and dissolution are affected by variations in the quantity of oxygen in the medium or by the presence of stabilizing molecules at the particle surface (Long et al. 2017), which thus impacts the release of silver ions. Furthermore, silver ions can be reduced by components such as biomolecules of the surrounding medium, thus leading to new nanoparticles and lower amount of free silver ions (Li et al. 2017; Pettegrew et al. 2014; Siddiqi et al. 2018). In addition, silver ions and nanoparticles can bind diverse compounds of the surroundings and form complex compounds with low affinity for the membrane of microbial cells. Their stability and dissociation property have then notable consequences on the bioavailability of silver (Liu et al. 2010). For example, usual components of biological and cell culture media such as chloride $\left(\mathrm{Cl}^{-}\right)$and phosphate $\left(\mathrm{PO}_{4}{ }^{3-}\right)$ ions have been reported to complex with silver ions (Choi et al. 2008; Navolotskaya et al. 2015). Silver retained in $\mathrm{AgCl}$ complexes may be particularly affected since the complex is highly insoluble $\left(\mathrm{pK}_{\mathrm{s}}=9.8\right)$ and may have very low capacity of binding with bacterial cell wall and membranes (Liu et al. 2010). Finally, silver nanoparticles, either newly formed or included as such for antibacterial action, can be coated by components present in the surroundings such as polysaccharides and proteins (Fig 1B), thus modifying their interactions with bacterial cells and the release of silver ions (Liu et al. 2010; Long et al. 2017).

Limitation of bioavailability induced by such silver-medium interactions is probably the main cause of variation of the Minimal Inhibitory Concentration (MIC) reported in the literature for silver ion solutions and nanoparticles suspensions. For a part, lack of method standardization for testing microbial susceptibility (e.g. in suspension in a nutritive aqueous medium, spread on a nutritive agargel medium, adhered on a material surface) including regarding exposure time and bacterial strains and species may explain some differences. However, interactions between silver and inorganic or organic compounds in the medium may also affect the MIC values by reducing the amount of silver ions available for an antibacterial action but the corresponding effects on final measurements is not known (Chopra 2007). For example, MIC values of silver ions on Escherichia coli (E. coli) species vary almost by a factor of $10^{3}$ according to medium (Table 1) (Choi et al. 2018; Swathy et al. 2014). For silver nanoparticles, comparison between the reported MIC values is even more complicated because of the variation of nanoparticles size, which is a factor known to strongly impact the action on bacterial cells (Ivask et al. 2014b). However, even for silver nanoparticles of similar size, MIC values on E. coli strains highly depend on the surrounding medium (Kędziora et al. 2018). In any case, whether and to which extent the medium affects MICs has not been precisely described so far. This can finally lead to report biased or inexact results about silver doses which are needed in colloidal suspensions or antimicrobial 
materials to trigger efficient inhibitory or bactericidal activity. This also prevents a correct comparison of antibacterial performances of various materials and coatings even when they display similar compositions (e.g. similar polymer matrix and nanoparticles composition and size).

A

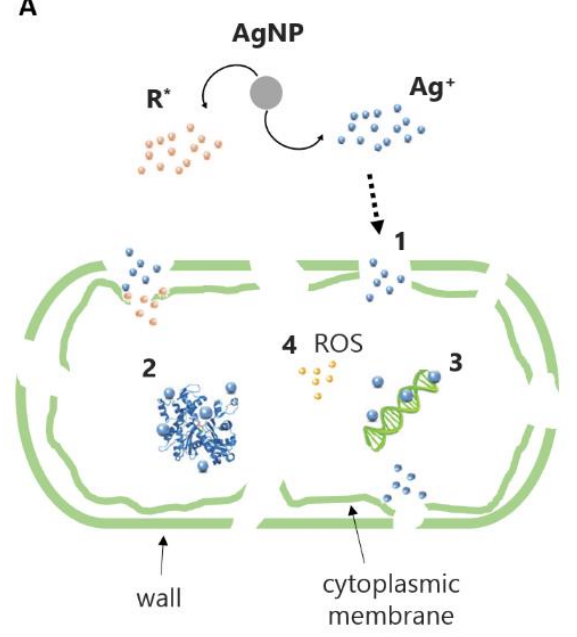

B

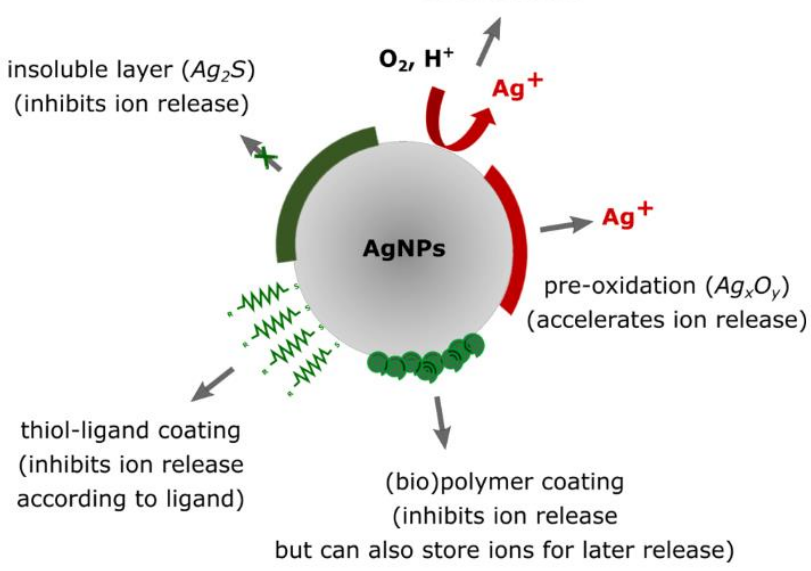

Fig 1 Mechanisms of antimicrobial action of silver: (A) Transport into the cell and microbiological targets of silver ions ( $R^{*}$ : Reactive Species, (1) Perforation of wall and plasmic membrane, (2) Inactivation of enzymes and other proteins, (3) Inhibition of DNA replication, (4) Oxidative stress); (B) Phenomena affecting dissolution of silver nanoparticles (inspired from (Le Ouay and Stellacci 2015; Liu et al. 2010))

In this framework, our aim is to quantify bioactive doses in specific biological media by providing information about the exact antimicrobial efficiency of silver nanoparticles and ions, in relation to the interactions of silver, especially silver ions, with some of the medium components. We investigated whether such interactions occur in three typical biological media and whether these affect the available, bioactive concentration of silver and therefore alter the inhibitory and bactericidal performances. The biological media were chosen for their typical composition complementarity regarding the inorganic and organic components and the nutritional intake they can enable: (i) nonnutritive, physiologic saline solution rich in chloride ions; (ii) nutritive, minimal medium rich in phosphate ions; (iii) nutritive, unselective medium rich in chloride ions and unidentified biomolecules. The study was conducted with silver nitrate solutions of a large range of concentration and with a suspension of silver nanoparticles obtained through a new synthesis process described elsewhere (Delmée et al. 2017). The main components formed in the solutions were identified and quantified. Qualitative and quantitative impacts of the diverse environments on the silver's antibacterial action 
was studied on E. coli bacterial cells. Damage in bacterial wall, growth inhibitory and cell cultivability were described. The rate of bioavailable silver was determined as well as the level of damage suffered by bacteria according to medium.

\section{Material and methods}

\section{Biological media.}

Three different biological media prepared in distilled and sterile water were used: $\mathrm{NaCl} 9 \mathrm{~g} / \mathrm{L}$ solution, M63G medium (Vidal et al. 1998) and Lysogeny broth (Sigma-Aldrich France), respectively called as "NaCl", "M63G" and "LB" in the following sections. Their compositions are reported in Table 1. They were sterilized by autoclaving at $121^{\circ}$ for $30 \mathrm{~min}$ before use.

\section{Silver ion solutions ( $\mathrm{AgNO}_{3}$ solutions).}

One initial solution of $\mathrm{AgNO}_{3}$ (Sigma-Aldrich France) was prepared in each sterile biological medium and in sterile water with a concentration of $10^{-1} \mathrm{M}$ (i.e. $10.8 \mathrm{~g} / \mathrm{L}$ ). Seven successive decimal dilutions were prepared from each initial solution, leading to concentrations from $10^{-2} \mathrm{M}$ to $10^{-8} \mathrm{M}$. Silver ions solutions are called "Ag-media" in general and "Ag-NaCl", "Ag-M63G" or "Ag-LB" according to medium.

\section{Silver nanoparticle (AgNPs) suspensions.}

AgNPs suspensions were prepared by liquid phase-pulsed laser ablation as described elsewhere (Delmée et al. 2017). Briefly a Nd:YAG laser SURELITE I10 from Continuum Company at a wavelength of $1064 \mathrm{~nm}$ was used with pulse duration of 5-7 ns and repetition rate of $10 \mathrm{~Hz}$. The silver target was washed in ethanol and rinsed with de-ionized water before being fixed on a rotating sample holder and immersed into de-ionized water. The silver target was rotated at a speed of $350 \mathrm{rpm}$ during $1 \mathrm{~min}$ of laser ablation allowing uniform etching and constant wear of the target for optimizing the nanoparticles dispersion in the solution. Total amount of silver in the suspension was determined by Inductively Coupled Plasma Mass Spectroscopy (ICP-MS 7900, Agilent) to be $79.6 \mu \mathrm{g} \mathrm{mL}^{-1}$. This suspension served as initial suspension to prepare AgNPs suspensions in biological media at concentrations of $0.8 \mu \mathrm{g} \mathrm{mL}^{-1}$ (1.0\% dilution) and $0.4 \mu \mathrm{g} \mathrm{mL}^{-1}$ (0.5\% dilution).

\section{Characterization of the $\mathrm{AgNO}_{3}$ solutions.}

Silver species present in the various $\mathrm{AgNO}_{3}$ solutions were determined and characterized by UV-vis absorption spectroscopy, X-Ray Diffraction (XRD), Transmission Electron Microscopy (TEM) and Dynamic Light Scattering (DLS). The precipitated and flocculated mass formed in $10^{-1} \mathrm{M} \mathrm{AgNO}_{3}$ solutions were harvested after $10 \mathrm{~min}$ centrifugation (Kruss) at $3000 \mathrm{rpm}$. They were washed 3 times with distilled water and oven dried at $37^{\circ} \mathrm{C}$ during 3 days in the dark before analysis. Supernatants 
were analyzed by UV-vis absorption spectroscopy $(250 \mathrm{~nm}-700 \mathrm{~nm})$ to detect the potential presence of silver nanoparticles (Perkin-Elmer Lambda 750). Morphology of these nanoparticles was evaluated by TEM with JEOL ARM200 equipment working at 200kV. Their size was determined by DLS experiments with a VASCO ${ }^{\mathrm{TM}}$ instrument (Cordouan technologies) working in the $2 \mathrm{~nm}-4 \mu \mathrm{m}$ range. Autocorrelation curves were obtained with a cumulative model for AgNPs suspensions in water and with a Pade-Laplace model for reduced $\mathrm{AgNO}_{3}$ solutions in culture medium (ISO 13320:2009 - Particle size analysis -- Laser diffraction methods ; ISO 22412:2017 Particle size analysis -- Dynamic light scattering (DLS)). In this last case, solutions were diluted 10 times before measurement to avoid any formation of big aggregates. Crystalline phases of the harvested mass were identified by search-match procedure using DIFFRAC.EVA software and COD (Gražulis et al. 2009) database by comparing their XRD patterns and reference patterns. Powder diffraction data were collected with a D8 Advance A25 Bragg-Brentano $\theta-\theta$ diffractometer from Bruker. This diffractometer is equipped with a LynxEye XET high resolution energy dispersive 1-D detector ( $\mathrm{Cu} K \alpha 1,2)$, and an automated motorized air scatter screen. Conditions for data collection are the following: range of $10-90^{\circ} 2 \theta$, step size of $0.01^{\circ} 2 \theta$, time per step of $0.5 \mathrm{~s}$ (total time par step: 96s), variable divergence slits (constant irradiated sample length: $15 \mathrm{~mm}$ ). Measurements were performed at room temperature, and automatically converted into fixed slits mode before search-match procedure.

The relative amounts of free $\mathrm{Ag}^{+}$in the three different $\mathrm{Ag}$-media were estimated in the supernatants by UV-vis absorption spectroscopy after reduction of silver ions with $\mathrm{NaBH}_{4}$ solution (from $810^{-3} \mathrm{M}$ for $10^{-1} \mathrm{M} \mathrm{AgNO}_{3}$ solutions to $810^{-10} \mathrm{M}$ for $10^{-8} \mathrm{M} \mathrm{AgNO}_{3}$ solutions).

The amount of silver present $\mathrm{as}^{\mathrm{Ag}^{+}}$or $\mathrm{Ag}^{0}$ species in each $\mathrm{Ag}$-medium was determined by Voltammetry measurements with a versaSTAT MC Princeton Applied Research potentiostat. These electrochemical analyses were performed with a carbon working electrode, a platinum counter electrode and a silversilver chloride reference electrode (SRE). These experiments were conducted with standard $\mathrm{AgNO}_{3}$ solutions in $\mathrm{KNO}_{3}(1 \mathrm{M})$ (Sigma-Aldrich France) to determine the exact potential leading to oxidation and reduction of $\mathrm{Ag}^{+} / \mathrm{Ag}^{0}$ couple. $\mathrm{KNO}_{3}$ was chosen for its high conductivity compared to water. Reduction potential was identified at $+0.550 \mathrm{mV} / \mathrm{SRE}$ by scanning potential range from $-2 \mathrm{~V} / \mathrm{SRE}$ to +2 V/SRE (at $10^{3} \mathrm{mV} \mathrm{s}^{-1}$ ). $\mathrm{Ag}^{+} / \mathrm{Ag}^{0}$ concentration measurements were then performed as follows: in a first step $\mathrm{Ag}^{+}$species were reduced onto the working electrode by applying a constant potential of +0.550 V/SRE during $1000 \mathrm{~s}$; in a second step $\mathrm{Ag}^{0}$ species deposited on the electrode or free in the solution were oxidized by scanning potential range from $0 \mathrm{~V} / \mathrm{SRE}$ to $2 \mathrm{~V} / \mathrm{SRE}\left(\right.$ at $10^{3} \mathrm{mV} \mathrm{s}^{-1}$ ). To insure the complete oxidation, the second step was reproduced several times until oxidation peak of $\mathrm{Ag}^{+} / \mathrm{Ag}^{0}$ was undetectable. Peak areas at $+0.550 \mathrm{~V} / \mathrm{SRE}$ on the resulting current versus potential curves were 
measured with SciDAVis ${ }^{\circledR}$ software and added to provide the silver amount initially present in the solution as $\mathrm{Ag}^{+}$or $\mathrm{Ag}^{0}$. Calibration of $\mathrm{Ag}^{+} / \mathrm{Ag}^{0}$ concentration versus peak area was performed in standard $\mathrm{AgNO}_{3}$ solutions from $10^{-1}$ to $10^{-7} \mathrm{M}$ in $\mathrm{KNO}_{3}$.

\section{Characterization of the AgNPs suspensions.}

AgNPs suspensions in water and media were characterized by UV-vis absorption spectroscopy to estimate the presence of nanoparticles and/or aggregates, by DLS to determine the size of the nanoparticles and by TEM to evaluate their morphology as previously described.

\section{Bacterial cultures in $\mathrm{AgNO}_{3}$ solutions and AgNPs suspensions.}

The antibacterial performances provided by the diverse $\mathrm{AgNO}_{3}$ solutions and $\mathrm{AgNPs}$ suspensions were determined on the fluorescent Escherichia coli (E. coli) SCC1 (Miao et al. 2009). Assays were conducted with bacterial cells initially stored at $-80^{\circ} \mathrm{C}$, thawed overnight on a LB-agar plate at $30^{\circ} \mathrm{C}$ and used to inoculate LB liquid medium with one colony for an overnight culture at $30^{\circ} \mathrm{C}$. The overnight culture was then centrifuged at $3000 \mathrm{rpm}$, supernatant was replaced by fresh medium ( $\mathrm{NaCl}, \mathrm{M} 63 \mathrm{G}$ or LB) and the pellet was gently re-suspended. After adjustment of their concentration at a $600 \mathrm{~nm}$ absorbance $\left(\mathrm{Abs}_{600 \mathrm{~nm}}\right.$ ) (Spectrawave diode 1200US) of 0.01 (i.e. $~ 510^{6}$ cells $/ \mathrm{mL}$ ), these bacterial suspensions were used to inoculate the $\mathrm{AgNO}_{3}$ solutions with a volume ratio of 1:9 of bacterial suspension in silver solution of same medium. Inoculation of the AgNPs suspensions was performed with volume ratios of 99:1 and 995:5 (bacterial suspension-to-silver solution in water) corresponding to total silver concentrations of $0.8 \mu \mathrm{g} / \mathrm{mL}\left(7.210^{-6} \mathrm{M}\right)$ and $0.4 \mu \mathrm{g} / \mathrm{mL}\left(3.610^{-6} \mathrm{M}\right)$ respectively. Control bacterial suspensions were made with the same volume ratios of bacterial suspension to water. All the bacterial suspensions were then incubated at $30^{\circ} \mathrm{C}$.

\section{Antibacterial properties of the silver solutions and suspensions.}

Effect of silver on bacterial population's growth was studied by following the concentration in bacterial cells of the diverse $\mathrm{AgNO}_{3}$ solutions and AgNPs suspensions. Abs ${ }_{600 \mathrm{~nm}}$ was measured by UV-vis absorption spectroscopy at $\Delta t=0 \mathrm{~h}, 1 \mathrm{~h}, 3 \mathrm{~h}, 24 \mathrm{~h}$ and $48 \mathrm{~h}$ after inoculation. Rate of population's reduction due to silver was calculated for each AgNPs suspension or $\mathrm{AgNO}_{3}$ solution in each medium by using Eq 1:

Reduction rate $(\%)=\left(1-\frac{A b s_{S B}-A b s_{S}}{A b s_{C B}-A b s_{C}}\right) \times 100$

where $A b s_{S B}$ and $A b s_{C B}$ are $A b s_{600 n m}$ measured for the given (i.e. $\mathrm{Ag}^{+}$concentration between $10^{-1} \mathrm{M}$ and $10^{-8} \mathrm{M}$ ) and control (i.e. without $\mathrm{Ag}^{+}$) solutions, respectively, with bacterial cells. $A b s_{s}$ and $A b s_{C}$ are Abs600nm measured for the given and control solutions, respectively, without bacteria, thus taking into 
account the coloration due to silver, from light yellow to light brown according to concentration of the solutions or suspensions. In $\mathrm{NaCl}$, bacterial population was expected not to growth with incubation time due to starvation, which may even lead to death of a part of the population inoculated in Ag-free control medium. Therefore, reduction rate in $\mathrm{NaCl}$ corresponds to the rate of bacteria died due to silver compared to Ag-free medium, while it is the result of inhibition of both proliferation and death of bacteria in M63G and LB.

Cultivability of the bacterial cells detected by $600 \mathrm{~nm}$ UV-vis absorption spectroscopy was evaluated by determining the number of colony-forming units (CFU). After $24 \mathrm{~h}$ of contact between bacterial cells and silver in $\mathrm{AgNO}_{3}$ solution or AgNPs suspension, $100 \mu \mathrm{L}$ of silver solution or suspension and their dilutions (from $10^{-1}$ to $10^{-9}$ when required) were spread on LB-agar plates and incubated for $24 \mathrm{~h}$ at $30^{\circ} \mathrm{C}$. CFU were counted and values were considered only if comprised between 30 to $300 \mathrm{CFU}$. Corresponding $\mathrm{CFU} / \mathrm{mL}$ values were calculated for the initial undiluted solutions and suspensions.

Silver activity on cell metabolic pathways and cell wall was evaluated by measuring the amount of cells able to produce GFP and by staining cells with propidium iodide (IP) (488 nm and $636 \mathrm{~nm}$ excitation and emission wavelength) (Invitrogen; $1 \mathrm{mg} / \mathrm{mL} M$ stock solution; $3 \mu \mathrm{L}$ stock solution/mL bacterial suspension) respectively. $10 \mu \mathrm{L}$ of each stained culture was deposited between glass slide and coverslip, 10 min oven dried $\left(37^{\circ} \mathrm{C}\right.$ ), mounted with $5 \mu \mathrm{L}$ of adequate solution (Mountant Permafluor ${ }^{\circledR}$, ThermoScientific) and incubated overnight at $30^{\circ} \mathrm{C}$. Solutions and suspensions were further analyzed under confocal fluorescence microscope (LSM700, Carl Zeiss; Plan-apochromat 63x/1.30 oil objective). Micrographs were randomly taken on 8 different locations for each culture sample. All fluorescent micrographs were treated and analyzed by using Image $J^{\circledR}$ V.1.44d software and plugins (Rasband 1997). Metabolically active $E$. coli cells were detected as green cells thanks to their chromosomic GFP inclusion, inactive $E$. coli cells with damaged membrane as red cells through IP staining and E. coli cells with active metabolism but damaged membrane as orange cells through the combination of IP staining and GFP expression.

\section{Reproducibility of the results and statistics.}

All biological experiments were reproduced at least three times. In each experimental replicate each culture condition was tested in two independent replicates. Then, results depicted in the Results section are average and standard deviation of at least six measurements. The significance of two-bytwo differences between the averages of green, orange or red cells number in the diverse culture conditions was evaluated by bilateral Student's t tests (application conditions: independent data and equal variances assessed by F-test) with significance thresholds of 0.01 and 0.05 . The alternative 
hypothesis $\left(\mu_{1} \neq \mu_{2}\right)$ was assumed to be true when the main hypothesis $\left(\mu_{1}=\mu_{2}\right)$ was rejected (Scherrer 2007).

\section{Results \& Discussion}

Our final aim was to provide guidance on the silver concentrations needed to get sufficient yet necessary antibacterial effects according to the type of aqueous, especially biological, media. Therefore, we determined the silver-containing components formed in diverse AgNPs suspensions and $\mathrm{Ag}^{+}$(i.e. $\mathrm{AgNO}_{3}$ ) solutions made in three different biological media, regarded as model aqueous surroundings, and we specified the fractions of silver remaining bioavailable for antibacterial activity in these various conditions. The associated antibacterial activity was measured in terms of population growth, bacterial cell cultivability and bacterial cell wall damages.

Three typical media used in biological and biomedical fields were selected based on their difference and complementarity in terms of composition and abundance in minerals and biomolecules as well as in their capacity to provide nutritional intake to bacterial cells: $\mathrm{NaCl}$ (physiological saline serum) is a pure mineral and non-nutrient medium, M63G is a minimal-nutrient, well defined mineral medium with moderate content in biomolecules, and LB is a nutrient-rich medium with high content in a large and unknown variety of biomolecules. Concentrations in total silver were $0.80 \mu \mathrm{gL}^{-1}$ (i.e. $7.210^{-6} \mathrm{M}$ ) or $0.40 \mu \mathrm{g} \mathrm{mL} L^{-1}$ (i.e. 3.6 $10^{-6} \mathrm{M}$ ) in AgNPs suspensions and from $10^{-1} \mathrm{M}$ to $10^{-8} \mathrm{M}$ in $\mathrm{AgNO}_{3}$ solutions.

Table 1 Antibacterial performances of $\mathrm{Ag}^{+}$reported for $\mathrm{E}$. coli in diverse media including those used in this study. They are expressed as $\mathrm{MIC}_{99-100}$ (from 99 to $100 \%$ of inhibition) or $\mathrm{MIC}_{50}$ (50\% of inhibition) (if specified in the publication). Medium's composition is indicated and components known for interactions with $\mathrm{Ag}^{+}$are specified with * symbol

\begin{tabular}{|c|c|c|c|}
\hline \multirow{2}{*}{ Medium } & \multirow{2}{*}{$\begin{array}{l}\text { Composition } \\
\text { (in } 1 \mathrm{~L} \text { water) }\end{array}$} & \multicolumn{2}{|c|}{$\mathrm{MIC}_{99-100}\left[\mathrm{MIC}_{50}\right]$ (E. coli strains) } \\
\hline & & $\mathrm{Ag}^{+}$ & AgNPs \\
\hline $\begin{array}{l}\text { Drinking } \\
\text { water }\end{array}$ & & $\begin{array}{l}510^{-7} \text { M (ATCC 10536) } \\
\text { (Swathy et al. 2014) }\end{array}$ & n.d. \\
\hline $\begin{array}{l}\text { Drinking } \\
\text { water }\end{array}$ & $1.3 \%$ nutrient broth & $\begin{array}{c}210^{-8} \mathrm{M}(1 \mathrm{~h})-210^{-7} \mathrm{M} \\
\text { (20min) (MTCC 433) } \\
\text { (Pathak and Gopal 2012) }\end{array}$ & n.d. \\
\hline $\mathrm{NaHCO}_{3}$ & $\mathrm{NaHCO}_{3}(0.17 \mathrm{mg})$ & n.d. & $\begin{array}{c}15 \mathrm{mg} \mathrm{L}^{-1}\left(1.410^{-4} \mathrm{M}\right) \\
(\mathrm{MG} 1655)\end{array}$ \\
\hline
\end{tabular}


(Long et al. 2017)

\begin{tabular}{|c|c|c|c|}
\hline $\mathrm{NaCl}$ & $\mathrm{NaCl}^{*}(9 \mathrm{~g})$ & n.d. & n.d. \\
\hline PBS & $\begin{array}{c}\mathrm{Na}_{2} \mathrm{HPO}_{4} *(0.85 \mathrm{~g}) \\
\mathrm{NaH}_{2} \mathrm{PO}_{4} *(0.22 \mathrm{~g}) \\
\mathrm{NaCl} *(8.5 \mathrm{~g})\end{array}$ & $\begin{array}{c}\leq 510^{-7} \mathrm{M} \text { (ATCC 25922) } \\
\text { (Jung et al. 2008) }\end{array}$ & n.d. \\
\hline M12 & $\begin{array}{c}\mathrm{KH}_{2} \mathrm{PO}_{4} *(2.0 \mathrm{~g}) \\
\left(\mathrm{NH}_{4}\right)_{2} \mathrm{SO}_{4} *(2.2 \mathrm{~g}) \\
\mathrm{MgSO}_{4} *(0.4 \mathrm{~g}) \\
\mathrm{FeSO}_{4} *(0.01 \mathrm{~g}) \\
\mathrm{Na}-\mathrm{citrate}(0.015 \mathrm{~g}) \\
\text { Glucose* }(1 \mathrm{~g})\end{array}$ & $\begin{array}{c}\mathrm{MIC}_{50}=2.310^{-6} \mathrm{M}(\mathrm{BL} 21) \\
\quad \text { (Yuting et al. 2017) }\end{array}$ & $\begin{array}{c}\mathrm{MIC}_{50}=2.25 \mathrm{mg} \mathrm{L}^{-1}(2.1 \\
\left.10^{-5} \mathrm{M}\right)(\mathrm{BL} 21) \\
\text { (Yuting et al. 2017) }\end{array}$ \\
\hline M9 & $\begin{array}{c}\mathrm{Na}_{2} \mathrm{HPO}_{4} *(6.7 \mathrm{~g}) \\
\mathrm{KH}_{2} \mathrm{PO}_{4} *(3.0 \mathrm{~g}) \\
\mathrm{NH}_{4} \mathrm{Cl} *(1.0 \mathrm{~g}) \\
\mathrm{NaCl}^{*}(0.5 \mathrm{~g}) \\
\mathrm{MgCl}_{2}^{*}(0.2 \mathrm{~g}) \\
\mathrm{CaCl}_{2}^{*}(0.011 \mathrm{~g}) \\
\text { Glucose* }(0.04 \mathrm{~g})\end{array}$ & $\begin{array}{c}310^{-6} \text { M (MG1655) } \\
\text { (Lok et al. 2007) }\end{array}$ & $\begin{array}{c}0.2 \mu \mathrm{g} \mathrm{L}^{-1}\left(210^{-9} \mathrm{M}\right) \\
(\mathrm{MG} 1655) \\
\text { (Lok et al. 2007) }\end{array}$ \\
\hline M63G & $\begin{array}{c}\mathrm{KH}_{2} \mathrm{PO}_{4} *(13.6 \mathrm{~g}) \\
\left(\mathrm{NH}_{4}\right)_{2} \mathrm{SO}_{4} *(2.0 \mathrm{~g}) \\
\mathrm{FeSO}_{4} *(0.5 \mathrm{mg}) \\
\mathrm{MgSO}_{4} *(0.2 \mathrm{~g}) \\
\mathrm{KOH}(4 \mathrm{~g}) \\
\text { Thiamine* }(0.5 \mathrm{mg}) \\
\text { Glucose* }(2 \mathrm{~g})\end{array}$ & $\begin{array}{c}\geq 310^{-5} \mathrm{M} \text { (HS2019) } \\
\text { (Sedlak et al. 2012) } \\
\text { (M63 with glucose } 0.2 \% \text { and } \\
18 \text { amino acids) }\end{array}$ & n.d. \\
\hline $\mathrm{BBL}^{\mathrm{TM}}$ & $\begin{array}{c}\text { Peptone (5 g) } \\
\text { Beef extract ( } 3 \mathrm{~g} \text { ) }\end{array}$ & $\begin{array}{c}4.210^{-6} \mathrm{M} \text { (PHL 628) } \\
\text { (Choi et al. 2008) }\end{array}$ & n.d. \\
\hline $\begin{array}{l}\text { Mueller- } \\
\text { Hinton }\end{array}$ & $\begin{array}{l}\text { Casein hydrolysate } \\
\qquad(17.5 \mathrm{~g}) \\
\text { Beef extract }(2 \mathrm{~g}) \\
\text { Starch (1.5 g) }\end{array}$ & n.d. & $\begin{array}{c}12 \mathrm{mg} \mathrm{L}^{-1}\left(10^{-4} \mathrm{M}\right)(\mathrm{DH} 5 \alpha) \\
\text { (Vazquez-Muñoz et al. } \\
\text { 2017) }\end{array}$ \\
\hline
\end{tabular}


Peptone (10 g)

LB

n.d.: no data or lack of information in the literature.

\section{Characterization of the AgNPs suspensions.}

The initial $79.6 \mu \mathrm{g} \mathrm{mL}^{-1} \mathrm{AgNPs}$ suspension contained a mono-dispersed population of nanoparticles of few tens nanometers size as indicated by the narrow Plasmon peak at $403 \mathrm{~nm}$ in UV-visible spectrum (Fig 2A). In addition, DLS measurement performed on a $1 \%$ dilution showed the presence of nanoparticles or aggregates of $69 \mathrm{~nm}$ besides the main population of $15 \mathrm{~nm}$ size nanoparticles (Supplementary Material, Table 1). TEM images coupled to EDX analysis confirmed the presence of almost spherical particles of between 10 and $30 \mathrm{~nm}$ and few sparse nanoparticles of less than $10 \mathrm{~nm}$ diameter (Fig 2B). After dilution in biological media, TEM images reveal that AgNPs are modified, showing general increase in the size compared to water (Fig $\mathbf{2 C}$ ). The changes differ with respect to the medium: In NaCl, the crystalline structure seems to be affected and frequent particles with size of more than $50 \mathrm{~nm}$ have formed, while some very small particles $(<10 \mathrm{~nm})$ are still visible in the surroundings; In M63G and LB, AgNPs display a similar crystalline structure as in water and nanoparticles with size less than $10 \mathrm{~nm}$ are rare or absent. In addition, AgNPs in LB are surrounded by a matrix forming shell around the nanoparticles. Knowing the composition of LB and the affinity between AgNPs and biomolecules (especially through thiol groups), matrix and shell may be attributed to a layer of biomolecules that coat nanoparticles (Liu et al. 2010; Long et al. 2017). In M63G, in contrast, biomolecules are rare, only consisting in thiamine (B1 vitamin) or glucose, and they are unlikely to adsorb on AgNPs surface in a quantity which is high enough to form visible matrix and shell.

A

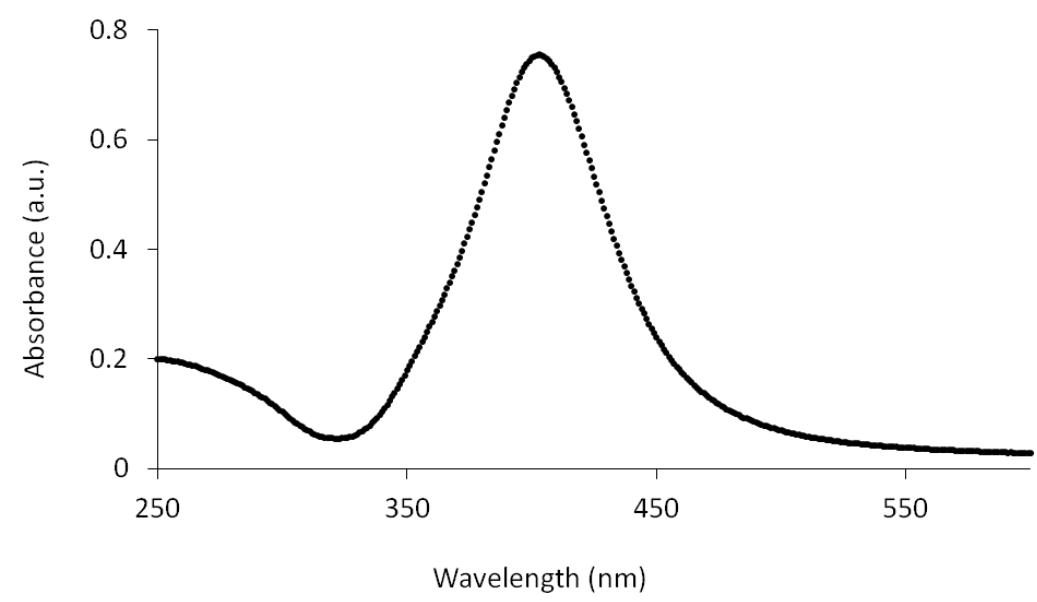




\section{B}

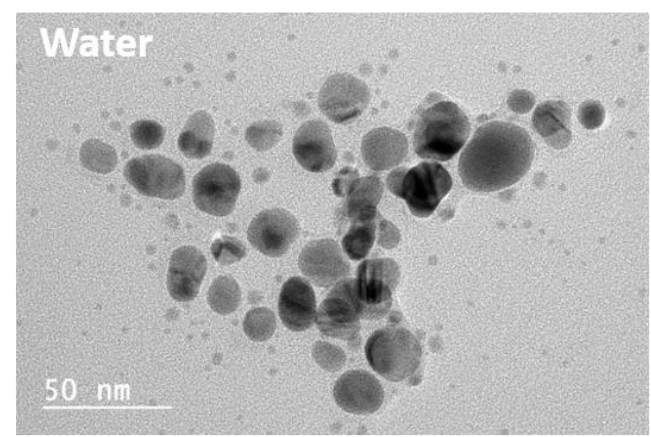

C
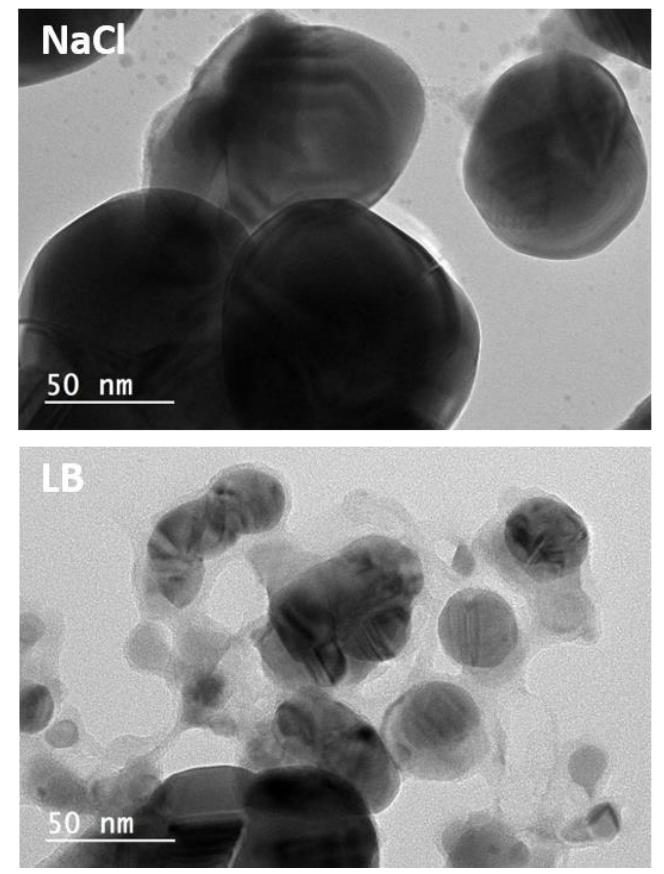

Fig 2 UV-vis absorption spectroscopy spectrum (A) and TEM images of AgNPs suspensions (79.6 $\mu \mathrm{g}$ $\mathrm{mL}^{-1}$ respectively) as obtained in water by laser ablation (B) and after dilution in $\mathrm{NaCl}, \mathrm{M} 63 \mathrm{G}$ and LB $\left(12 \mu \mathrm{g} \mathrm{mL} \mathrm{L}^{-1}\right)(\mathrm{C})$

\section{Antibacterial performances of the AgNPs suspensions.}

Based on growth kinetics measured in each medium (Supplementary Material, Fig 1), reduction rates of the bacterial population were determined in the nanoparticle suspensions made in the three different media, compared to the growth measured in the corresponding Ag-free control medium. As depicted in Fig 3A, reduction rates in AgNPs suspensions compared to Ag-free cultures varied a lot with the medium: after $3 \mathrm{~h}$ of contact with AgNPs, population growth was almost completely reduced in M63G compared to Ag-free solution, while growth of the bacterial population was only affected by $20 \%$ in LB. After $24 \mathrm{~h}$ of contact with AgNPs, trends were similar in both media with even less inhibitory effect in LB. In NaCl, reduction rate also reached $100 \%$ of cells in both AgNPs suspension. These results suggest that bacterial cells were rapidly damaged by AgNPs in a sufficient dramatic way to kill bacteria and to induce their lysis in $\mathrm{NaCl}$ (since no proliferation is expected in this medium) and to prevent 
growth of population in M63G by disturbing proliferation and/or by killing bacteria. In contrast, cells were only weakly affected in LB allowing the population to almost completely recover a normal growth after $24 \mathrm{~h}$ of culture. The total silver concentrations of $15 \mathrm{~nm}$ sized AgNPs that are able to completely inhibit the bacterial population's growth or completely kill the bacterial population in the three media are estimated to be more than $10^{-5} \mathrm{M}$ in LB but less than $10^{-6} \mathrm{M}$ in $\mathrm{M} 63 \mathrm{G}$ and $\mathrm{NaCl}$. This can be considered to be in agreement with the literature despite the lack of reported data for $\mathrm{M} 63 \mathrm{G}$ and $\mathrm{NaCl}$. Indeed, whatever the medium, MIC values reported for AgNPs are comprised in a large range from 0.2 $\mu \mathrm{g} / \mathrm{L}$, i.e. $1.410^{-4} \mathrm{M}$, to $15 \mathrm{mg} / \mathrm{L}$, i.e. $210^{-9} \mathrm{M}$ (Kędziora et al. 2018; Lok et al. 2007; Long et al. 2017). In addition, these results demonstrate that growth inhibitory and death efficiencies of AgNPs are strongly affected by the medium, with a factor of more than 10 between M63G or $\mathrm{NaCl}$ and LB.

Physiologic and metabolic states of the cells remaining in the AgNPs suspensions after $3 \mathrm{~h}$ of culture were specified by measuring the amounts of cells stained by propidium iodide and/or able to produce GFP (Fig 3B). As shown in Fig 3C, about $10 \%$ of bacteria displayed a damaged cell wall (red and orange) in LB whereas this percentage of damaged bacteria is up to 50\% in M63G. In addition, among damaged cells, bacteria showing metabolic inactivity (red) were 10\% in LB but more than 20\% in M63G. Knowing that bacteria tested by this experiment are those remaining after $3 \mathrm{~h}$ of contact with silver, a percentage lower than 1\% of bacteria are still active in M63G but more than $50 \%$ in LB (see the graphical summary in Fig 8). This result confirms that the efficiency of AgNPs is much lower in LB compared to M63G. It is also consistent with the difference of cell growth observed in the different media between $3 \mathrm{~h}$ and $24 \mathrm{~h}$ of contact with AgNPs. Indeed, only metabolic-active cells without a damaged wall are prone to correctly proliferate (Cangelosi and Meschke 2014; Oliver 2005). As a result, almost no population growth was possible in M63G due to the quasi-absence of bacteria, whereas cells in LB were able to proliferate and thus were still in a large amount.

After 24h of contact with AgNPs, bacterial cells in LB were cultivable exactly like cells in Ag-free LB. In contrast, cell cultivability in AgNPs-containing $\mathrm{NaCl}$ and M63G was reduced by $1.5 \log _{10}$ and $3.2 \log _{10}$ compared to Ag-free medium in $\mathrm{NaCl}$ and $\mathrm{M} 63 \mathrm{G}$, respectively. The assay even failed to detect any cultivable cell in AgNPs suspension with the highest concentration $\left(0.80 \mu \mathrm{g} \mathrm{mL}^{-1}\right)$ in M63G. Therefore, inhibition and death of the bacterial population can be considered as complete at this concentration in M63G.

AgNPs with diameter smaller than $20 \mathrm{~nm}$ are usually expected to reveal notable inhibitory and bactericidal effects in every medium (Agnihotri et al. 2014; Ivask et al. 2014b; Palza 2015; VazquezMuñoz et al. 2017). However, as shown by TEM and EDX analysis, AgNPs in LB are coated here by a 
matrix which is probably made of biomolecules and coming from the medium. This biomolecular shell may prevent inhibitory and bactericidal effect of AgNPs in a more marked manner in LB compared to in $\mathrm{M} 63 \mathrm{G}$ and $\mathrm{NaCl}$. Indeed, antibacterial activity of AgNPs has been reported as highly changing with ligands such as proteins or other biopolymers such as polysaccharides, that may bind the nanoparticles (Liu et al. 2010; Long et al. 2017): the oxidative stress is then partly prevented and $\mathrm{Ag}^{+}$release rate is much reduced. Since inhibitory and bactericidal actions of AgNPs are caused for a large part by the released $\mathrm{Ag}^{+}$species, this reduction may strongly affect the antibacterial efficiency. In addition, even though it is still controversial, direct effect of AgNPs through their uptake by bacterial cells may occur. It may be also affected in LB due to the prevention of the cell-nanoparticle contact if AgNPs are embedded in a matrix and due to the increase of the AgNPs size resulting from the biomolecule coating. Besides, $\mathrm{Ag}^{+}$species are in contact with all the medium compounds immediately after release, thus prone to interact with them. Such interactions, e.g. with chloride ions and thiol-containing compounds, are known to reduce bioavailability of silver ions for antibacterial effects or cell toxicity (Hogstrand and Wood 1998).

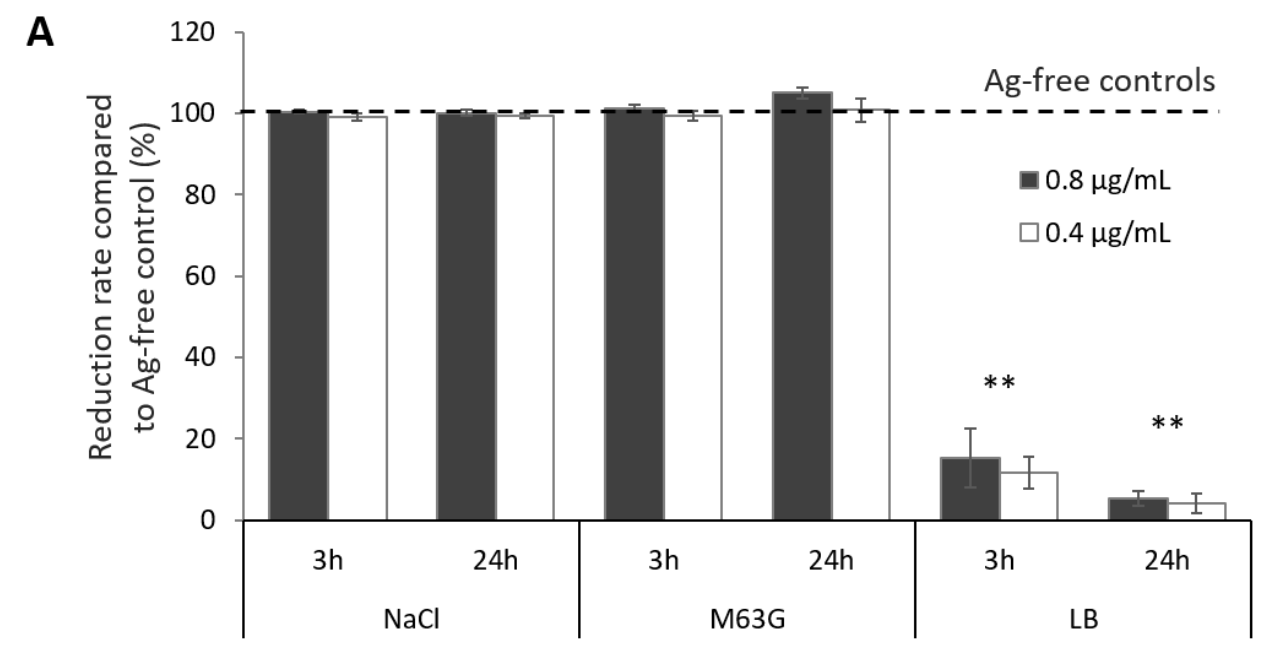

B

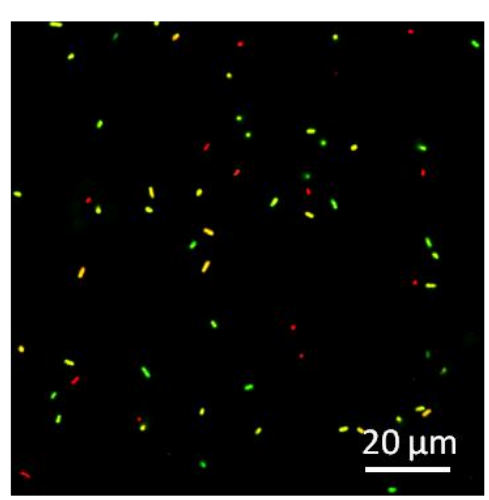




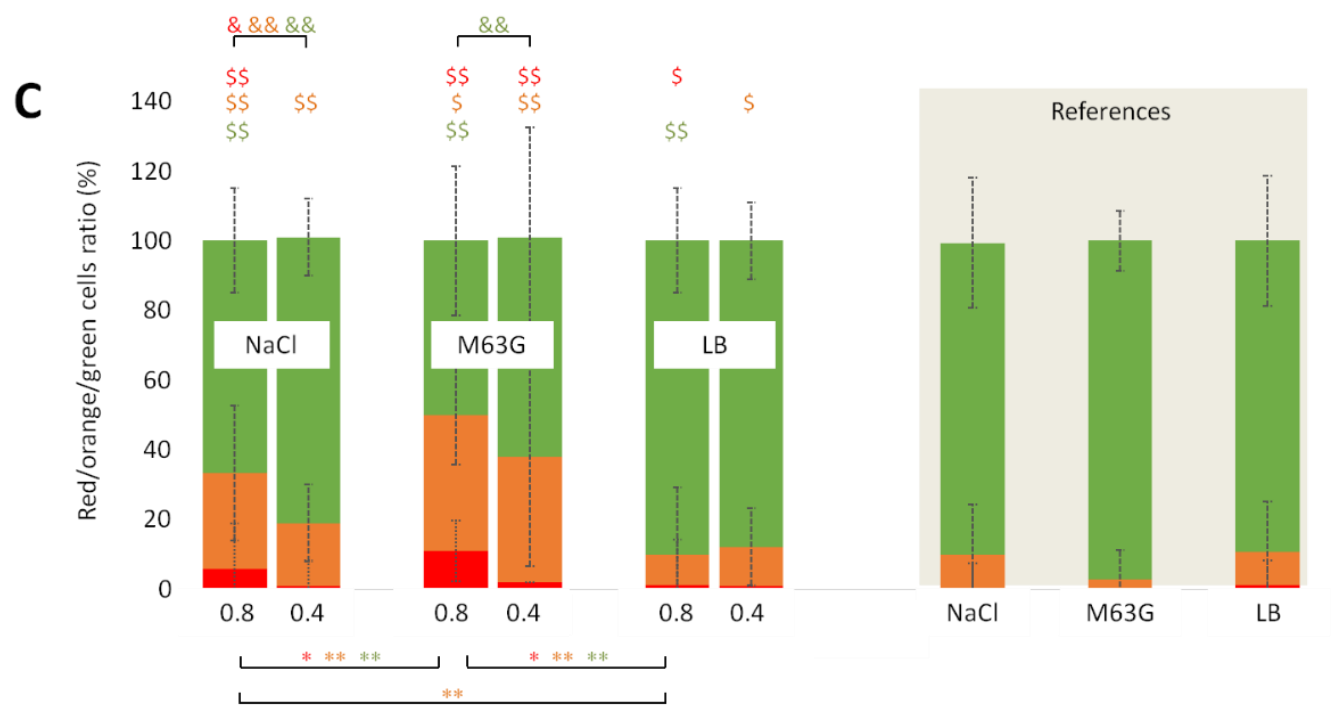

Fig 3 Impact of silver nanoparticles suspensions $\left(0.8 \mu \mathrm{g} \mathrm{L}^{-1}\right.$ and $\left.0.4 \mu \mathrm{g} \mathrm{L}^{-1}\right)$ on E. coli SCC1 population growth in $\mathrm{NaCl}, \mathrm{M} 63 \mathrm{G}$ and $\mathrm{LB}$, displayed (A) as reduction rate after $3 \mathrm{~h}$ and $24 \mathrm{~h}$ of exposition compared to controls (100\%), (B) as fluorescence confocal micrograph after propidium iodide labeling (example of micrograph) and (C) as the resulting ratios of intact, damaged but active and inactive cells after $3 \mathrm{~h}$ of exposition to silver (labeling of difference significance of $0.4 \mu \mathrm{g} / \mathrm{mL}$ is similar to $0.8 \mu \mathrm{g} / \mathrm{mL}$ except for M63G versus $\mathrm{NaCl}$ which are not different in terms of damaged and metabolically active (i.e. orange) cells). Significant differences are displayed by $\$, \&$ and * symbols for comparison to reference, to the other concentration in the medium, and to another medium with the same concentration. Green, orange or red color of symbol refers to ratio of (i) intact, (ii) damaged but active and (iii) inactive cells, respectively. One and two symbols refer to $p$-value $<0.5 \%$ and $0.05 \%$ respectively

\section{Characterization of the $\mathrm{AgNO}_{3}$ solutions.}

Silver species, complexes and precipitates formed by silver ions in the three various Ag-media as well as of their corresponding amounts composition were studied in $10^{-1} \mathrm{M} \mathrm{AgNO}_{3}$ solutions. Different precipitates naturally settled in the different media (Fig 4A). They were dense in $\mathrm{NaCl}$ and M63G while more diffuse in $L B$, and they corresponded to $57 \pm 11 \%, 31 \pm 8 \%$ and $6 \pm 3 \%$ of the dry mass (i.e. $\mathrm{AgNO}_{3}$ and medium components) in $\mathrm{NaCl}, \mathrm{M} 63 \mathrm{G}$ and LB, respectively. XRD analysis revealed that $\mathrm{AgCl}$ was the only crystalline complex detectable in $\mathrm{NaCl}$ and LB precipitates (Fig 4B \& D), which trapped $103 \pm 19 \%$ and $17 \pm 8 \%$ of the initial dissolved quantity of silver in $\mathrm{NaCl}$ and $\mathrm{LB}$ respectively. Some additional compounds, probably amorphous for a part, were suspected to also exist in the LB precipitate as suggested by the curved background and by some weak unidentified peaks (Fig 3D, inset). In M63G, three phases $\left(\mathrm{Ag}_{3} \mathrm{PO}_{4}, \mathrm{KOH}\right.$ and $\left.\mathrm{KH}_{2} \mathrm{PO}_{4}\right)$ were detected beside weak signals due to the anode (i.e. $\mathrm{W}$ 
L $\alpha 1$ wavelength contribution), corresponding to circa $98 \% w t, 1 \% w t$ and $1 \% w t$ of the precipitate, respectively. Due to the high solubility of $\mathrm{KOH}$ and $\mathrm{KH}_{2} \mathrm{PO}_{4}$ phases and knowing that they were detected in much higher quantities before washing the precipitates, these phases are attributed to a rest of supernatant entrapped in the precipitate during the harvest. $\mathrm{Ag}_{3} \mathrm{PO}_{4}$ is therefore probably the only crystalline complex in the M63G precipitate. Thus, $\mathrm{Ag}_{3} \mathrm{PO}_{4}$ complex was estimated to trap $86 \pm 22 \%$ of the initial quantity of silver dissolved in M63G. It must be noticed that $\mathrm{Ag}_{2} \mathrm{SO}_{4}$ compound is also expected to form in M63G but was not detected. Nevertheless, $\mathrm{SO}_{4}{ }^{2-}$ concentration in M63G is about 50 times lower than $\mathrm{PO}_{4}{ }^{3-}$ and the solubility of $\mathrm{Ag}_{2} \mathrm{SO}_{4}$ is about 10 times higher than those of $\mathrm{Ag}_{3} \mathrm{PO}_{4}$. Therefore, $\mathrm{Ag}_{2} \mathrm{SO}_{4}$ cannot exceed $2 \% \mathrm{w}$. of $\mathrm{Ag}_{3} \mathrm{PO}_{4}$ amount, which is close to the XRD detection limit for a crystalline compound in such a weight concentration. 

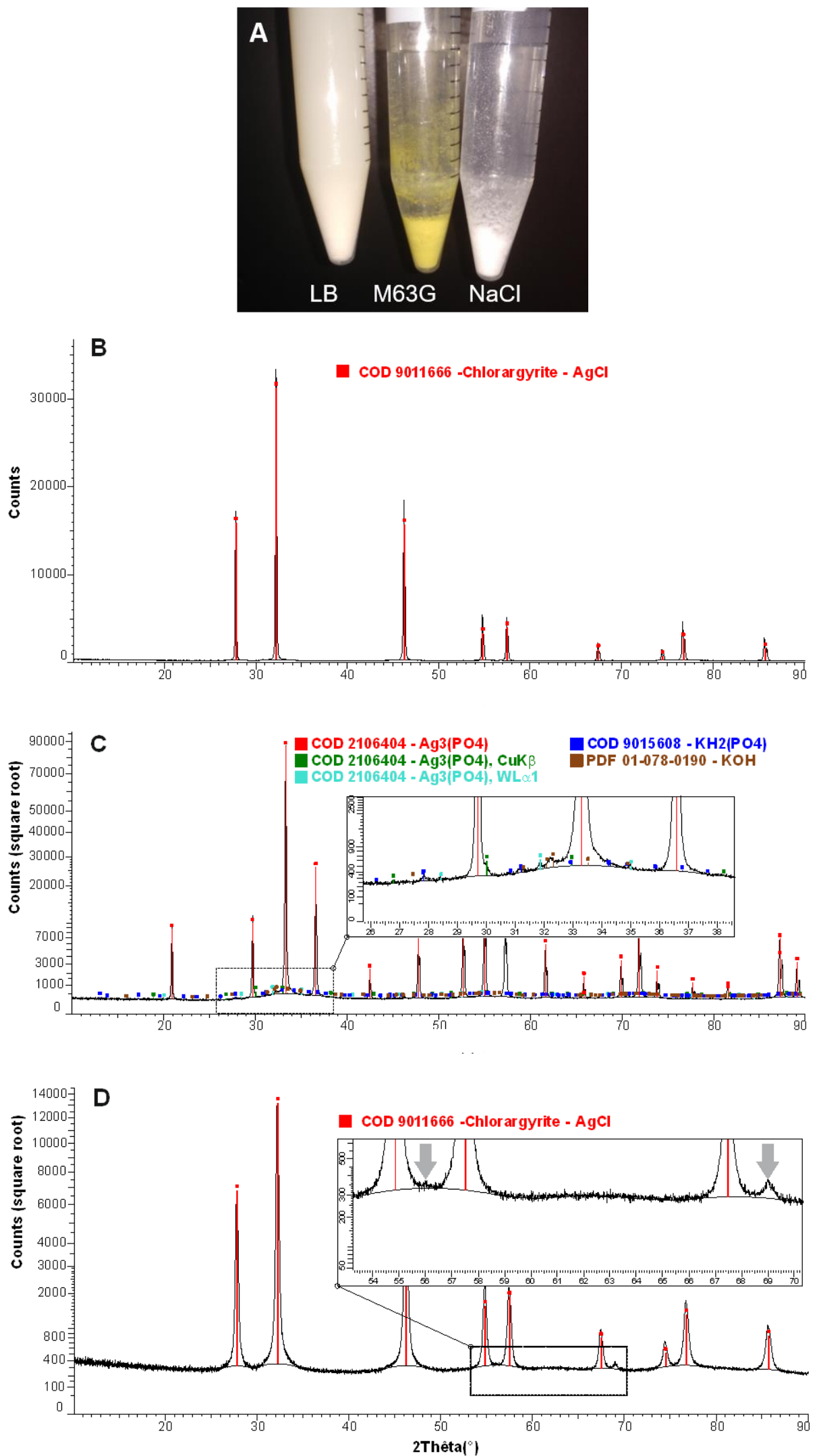

Fig 4 Photographs $(A)$ and $X$-ray powder diffratograms $(B, C, D)$ of precipitates formed in $\mathrm{AgNO}_{3}$ solutions $\left(10^{-1} \mathrm{M}\right)$ in $\mathrm{NaCl}$ 9g/L (B), M63G (C) and LB (D), with identification of the detectable crystalline phases. For LB (D), peaks of unknown impurities are marked by grey arrows 
In addition, silver ions may have been reduced into $\mathrm{Ag}^{0}$ by medium components acting as reducing agents. However, the detection by XRD analysis and by UV-vis absorption spectroscopy of newly formed AgNPs was limited by their low quantity (Supplementary Material, Fig 2). In contrast, DLS analysis demonstrated the presence of nanoparticles and aggregates of size between about $150 \mathrm{~nm}$ and $2 \mu \mathrm{m}$ in M63G and between about $25 \mathrm{~nm}$ and $230 \mathrm{~nm}$ in $10^{-4} \mathrm{M}$ solutions in LB (Supplementary Material, Table 1). This was confirmed by TEM analysis in M63G (Fig 5A,B) and LB (Fig 5C,D) while both DLS and TEM failed to detect any nanoparticle in NaCl. These nanoparticles formed in M63G and LB were shown by EDX analysis to contain silver and they probably resulted from the reduction of $\mathrm{Ag}^{+}$by glucose in M63G and other thiol-containing biomolecules in LB (Peterson et al. 2007; Pettegrew et al. 2014; Raveendran et al. 2003). Nevertheless, it cannot be asserted whether the nanoparticles were only pure AgNPs since Ag species were also accompanied by $\mathrm{P}$ species in $\mathrm{M} 63 \mathrm{G}$ and $\mathrm{Cl}$ species in $\mathrm{LB}$, as detected by EDX (Fig $\mathbf{5 E}, \mathbf{F}$ ).
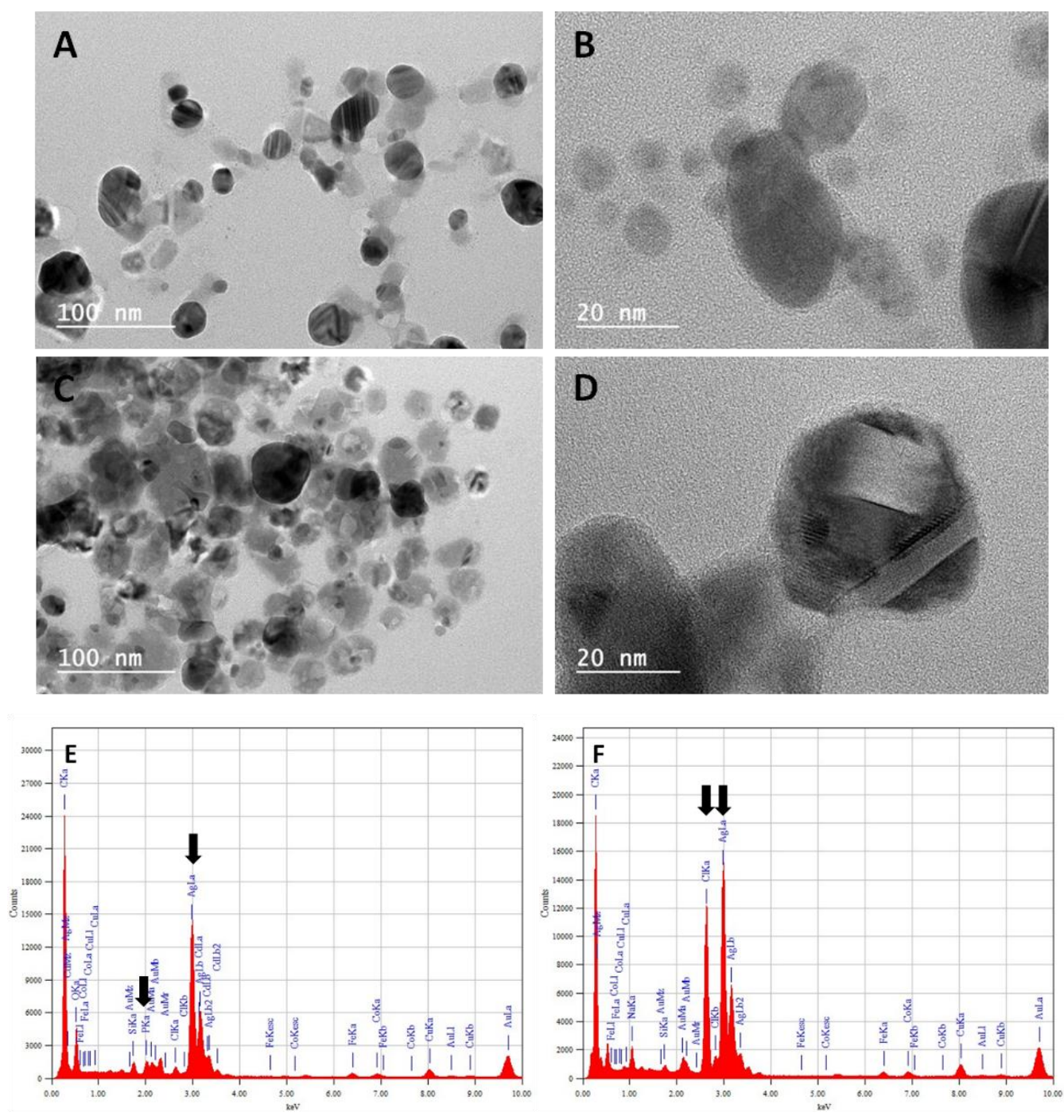

Fig 5 TEM images (A-D) and EDX spectra $(E, F)$ of supernatants of $\mathrm{AgNO}_{3}$ solutions $\left(10^{-1} \mathrm{M}\right)$ in $\mathrm{M} 63 \mathrm{G}$ $(A, B, E)$ and $L B(C, D, F) . \mathrm{AgNO}_{3}$ solutions in $\mathrm{NaCl}$ were free of nanoparticles 
The quantity of free silver ions in Ag-media failed to be measured with precision by UV-vis absorption spectroscopy. This was due to complex nanoparticles that formed after reduction by $\mathrm{NaBH}_{4}$ of $\mathrm{Ag}^{+}$into $\mathrm{Ag}^{0}$ species including other components of the medium. Accordingly, the general shape of absorption peaks reveals broadening and shift towards higher wavelength than for silver plasmon $(400 \mathrm{~nm}$ in water) (Mogensen and Kneipp 2014). However, by comparing the relative absorbance intensities, the quantity of free $\mathrm{Ag}^{+}$was estimated to follow the decreasing order as: $\mathrm{Ag}-\mathrm{H}_{2} \mathrm{O}>\mathrm{Ag}-\mathrm{M} 63 \mathrm{G}>\mathrm{Ag}-\mathrm{LB} \geq$ $\mathrm{Ag}-\mathrm{NaCl}$ (maximal intensity at $400 \mathrm{~nm}$ of about 1.0, 0.5, 0.10 and 0.05 in the respective solutions) (Supplementary Material, Fig 3).

Exact amount of silver present as ionic $\left(\mathrm{Ag}^{+}\right)$or metallic $\left(\mathrm{Ag}^{0} / \mathrm{AgNPs}\right)$ species in $\mathrm{Ag}$-media has been measured by voltammetry measurements except in $\mathrm{NaCl}$ medium due to technical reason (i.e., reference electrode of saturated silver chloride). A typical voltammogram obtained in a $\mathrm{KNO}_{3}$ reference medium is depicted in Supplementary Material, Fig 4A. The calibration curve was obtained after measurements in $\mathrm{KNO}_{3}$ medium with a range of $\mathrm{AgNO}_{3}$ concentrations from $10^{-7} \mathrm{M}$ to $10^{-1} \mathrm{M}$ (Supplementary Material, Fig 4B). As depicted in the inset, peak areas under 0.25 a.u. provided insufficient precision to distinguish concentrations under $510^{-5} \mathrm{M}$. Therefore, even though all measurements were taken into account if detectable, only peak areas higher than 0.3 a.u. were considered for the exact calculation of silver concentrations. Results are summarized in Supplementary Material, Table 2. The quantity of silver present as $\mathrm{Ag}^{+}$and $\mathrm{Ag}^{0}$ species varied from $3 \%$ to $11 \%$ of the initial quantity of $\mathrm{Ag}^{+}$dissolved in M63G and was less than $1 \%$ of the quantity initially dissolved in $\mathrm{LB}$. For concentrations lower than $10^{-5} \mathrm{M}$ in $\mathrm{M} 63 \mathrm{G}$ and $10^{-3} \mathrm{M}$ in $\mathrm{LB}$, silver was not detectable. This indicates that a maximum of about $10 \%$ and $1 \%$ of the dissolved silver existed as $\mathrm{Ag}^{+}$ or $\mathrm{Ag}^{0}$ species in M63G and LB, respectively, which implies that about $90 \%$ and $99 \%$ of the silver, respectively, was retained in complexes or other compounds whatever the initial $\mathrm{AgNO}_{3}$ concentration.

The quantity of silver no longer available in the media is approximately the one which is estimated to be retained in $\mathrm{Ag}_{3} \mathrm{PO}_{4}$ precipitates in $\mathrm{M} 63 \mathrm{G}$, based on XRD analysis (86 $\pm 22 \%$ ) but much higher than the

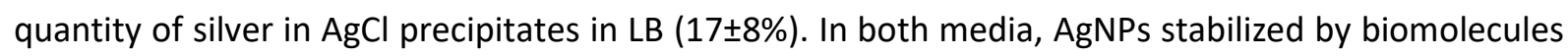
through Ag-S bonds (thiamine (Khan et al. 2018) in M63G and other proteins or polysaccharides (Jyoti et al. 2016; Siddiqi et al. 2018) in LB) probably retained a significant part of the silver ions which are initially dissolved in the medium (0-33\% in M63G, 74-91\% in LB) and detected neither as $\mathrm{Ag}^{+} / \mathrm{Ag}^{0}$ nor as crystalline precipitate. In addition, silver was also probably retained as $\mathrm{Ag}_{2} \mathrm{SO}_{4}$ complex in $\mathrm{M} 63 \mathrm{G}$ and as $\mathrm{Ag}^{+}$bound to thiol-containing biomolecules in LB. All these silver species are undetectable at the potential used for the voltammetry analysis. As a result, composition of $\mathrm{AgNO}_{3}$ solutions in $\mathrm{M} 63 \mathrm{G}, \mathrm{LB}$ 
and $\mathrm{NaCl}$ in terms of silver compounds are estimated to be as following (also depicted in Fig 6B): In LB, $\mathrm{Ag}^{+}$or $\mathrm{AgNPs}$ bound to biomolecules (74-91\%), $\mathrm{AgCl}(9-25 \%)$ and $\mathrm{Ag}^{+} / \mathrm{Ag}^{0}$ (i.e. $\left.\mathrm{AgNPs}\right)(\leq 1 \%)$; In $\mathrm{NaCl}$, $\mathrm{AgCl}(84-100 \%)$ and $\mathrm{Ag}^{+} / \mathrm{Ag}^{0}$ (i.e. AgNPs) (0-16\%); In M63G, $\mathrm{Ag}_{3} \mathrm{PO}_{4}$ (64-100\%), $\mathrm{Ag}^{+} / \mathrm{Ag}^{0}$ (i.e. AgNPs) (3-11\%) and $\mathrm{Ag}_{2} \mathrm{SO}_{4} / \mathrm{Ag}^{+}$or AgNPs bound to biomolecules (0-33\%).

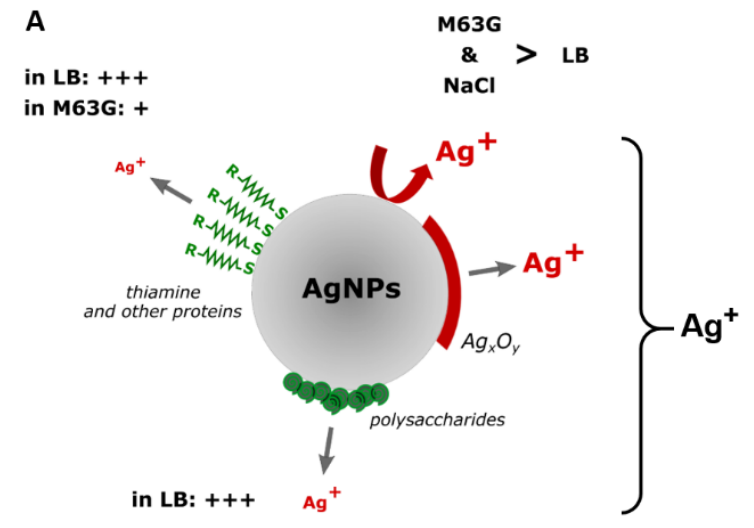

B

\begin{tabular}{|c|c|c|c|}
\hline & $\mathrm{Ag}^{+} / \mathrm{Ag}^{0}$ (AgNPs) & $\begin{array}{l}\text { Precipitate } \\
\left(\mathrm{Ag}_{3} \mathrm{PO}_{4}^{\#}\right. \\
\left.\text { or } \mathrm{AgCl}^{\S}\right)\end{array}$ & Others \\
\hline $\mathrm{NaCl}$ & $0-16 \%$ & $84-100 \%^{\S}$ & $0 \%$ \\
\hline M63G & $3-11 \%$ & $64-100 \% \#$ & $0-33 \%^{1}$ \\
\hline$\angle B$ & $\leq 1 \%$ & $9-25 \%^{\S}$ & $74-91 \%^{2}$ \\
\hline
\end{tabular}

Fig 6 Fate of silver nanoparticles and ions according to the medium ( $\mathrm{NaCl}, \mathrm{M} 63 \mathrm{G}$ or LB). (A) Phenomena probably affecting dissolution of silver from nanoparticles. (B) Fractions of silver ions in the various possible compounds

\section{Antibacterial performances of the $\mathrm{AgNO}_{3}$ solutions.}

Changes in antibacterial performances according to the medium were evaluated by measuring the rates of population reduction, damaged cells and cultivable cells in $\mathrm{AgNO}_{3}$ solutions and the corresponding Ag-free media. As depicted in Fig 7A, reduction rates increased with $\mathrm{AgNO}_{3}$ concentration for all the media. Complete inhibition of the population growth was reached in the tested range of $\mathrm{AgNO}_{3}$ concentration. As noted above, this is due to death of inoculated bacterial cells in $\mathrm{NaCl}$, i.e. nonnutritive medium, and to a combination of death and proliferation inhibition in M63G and LB. However, MIC depended on the medium: It was of $10^{-6} \mathrm{M}$ in M63G but of $10^{-4} \mathrm{M}$ in LB and $\mathrm{NaCl}$. This is in agreement with values already published for E. coli K12 KCTC1116 in LB (>9 10 $0^{-5} \mathrm{M}$ (Choi et al. 2018)) and for E. coli K12 MC4100 in M63G supplemented with $50 \mathrm{mg} / \mathrm{mL}$ of amino acids (3.7 10${ }^{6} \mathrm{M}$ (Sedlak et al. 2012)). Regarding $\mathrm{NaCl}$, exact $\mathrm{MIC}$ values of $\mathrm{Ag}^{+}$in $\mathrm{NaCl}$ is missing in the literature but complexation of $\mathrm{Ag}^{+}$with chloride ions is usually expected to provide strong reduction of the silver efficiency (Liu et al. 2010; Swathy et al. 2014).

Intensity of the membrane damage and metabolic activity in the bacterial cells remaining after $3 \mathrm{~h}$ of contact with silver is different between M63G and LB. Fractions of damaged (i.e. red or orange cells) and inactive (i.e. red) bacteria significantly increase with $\mathrm{AgNO}_{3}$ concentration in both media (Fig 7B). However, fractions of bacterial cells with damaged membrane were at least two times higher in M63G 
compared to $\mathrm{LB}$ whatever the $\mathrm{AgNO}_{3}$ concentration. These fractions even reached $50 \%$ of the bacterial population in $10^{-8} \mathrm{M} \mathrm{AgNO}_{3} \mathrm{M} 63 \mathrm{G}$ but only $1 \%$ in $10^{-8} \mathrm{M} \mathrm{AgNO}_{3} \mathrm{LB}$. In addition, the complete elimination of active bacteria, i.e. green cells, was never achieved in LB over the whole range of concentration but was possible in M63G for concentrations of $10^{-2} \mathrm{M}$ or greater. Similar effects are observed for $\mathrm{M} 63 \mathrm{G}$ and $\mathrm{LG}$ when the $\mathrm{AgNO}_{3}$ concentration is changed by more than 2 decimal dilutions, which is consistent with the difference observed for MIC values. Furthermore, inactivation of cells is largely incomplete in $\mathrm{NaCl}$ medium even with the highest $\mathrm{AgNO}_{3}$ concentrations, which is in accordance with the low quantity of free and bioactive silver in this medium. However, the fraction of intact cells (i.e. green) was low whatever $\mathrm{AgNO}_{3}$ concentration, the largest part of cells being active but with permeable membrane. This is assigned to the higher cell permeability induced by nutrient limitation, which thus enhanced intake of IP dye into bacterial cells (Audrey et al. 1999; Liu and Ferenci 1998).

After $24 \mathrm{~h}$ of contact with $\mathrm{Ag}^{+}$, bacteria were all cultivable in $\mathrm{NaCl}$ and $\mathrm{LB}$ for concentration of $\mathrm{AgNO}_{3}$ of $10^{-6} \mathrm{M}$, whereas the population of cultivable bacteria was reduced by $2.1 \log _{10}$ in $\mathrm{M} 63 \mathrm{G}$ compared to Ag-free medium. Thus, silver in M63G exhibited a much higher efficacy regarding hindrance of bacterial cultivability than silver in $\mathrm{LB}$ and $\mathrm{NaCl}$, as well as this was shown before regarding growth inhibition, membrane damage and bacterial activity. However, no cultivable cell was measured whatever the medium for concentrations above $10^{-4} \mathrm{M}$. This demonstrates that cells were all affected by silver even though they were not lysed and therefore they were still detectable by absorbance measurements at $600 \mathrm{~nm}$

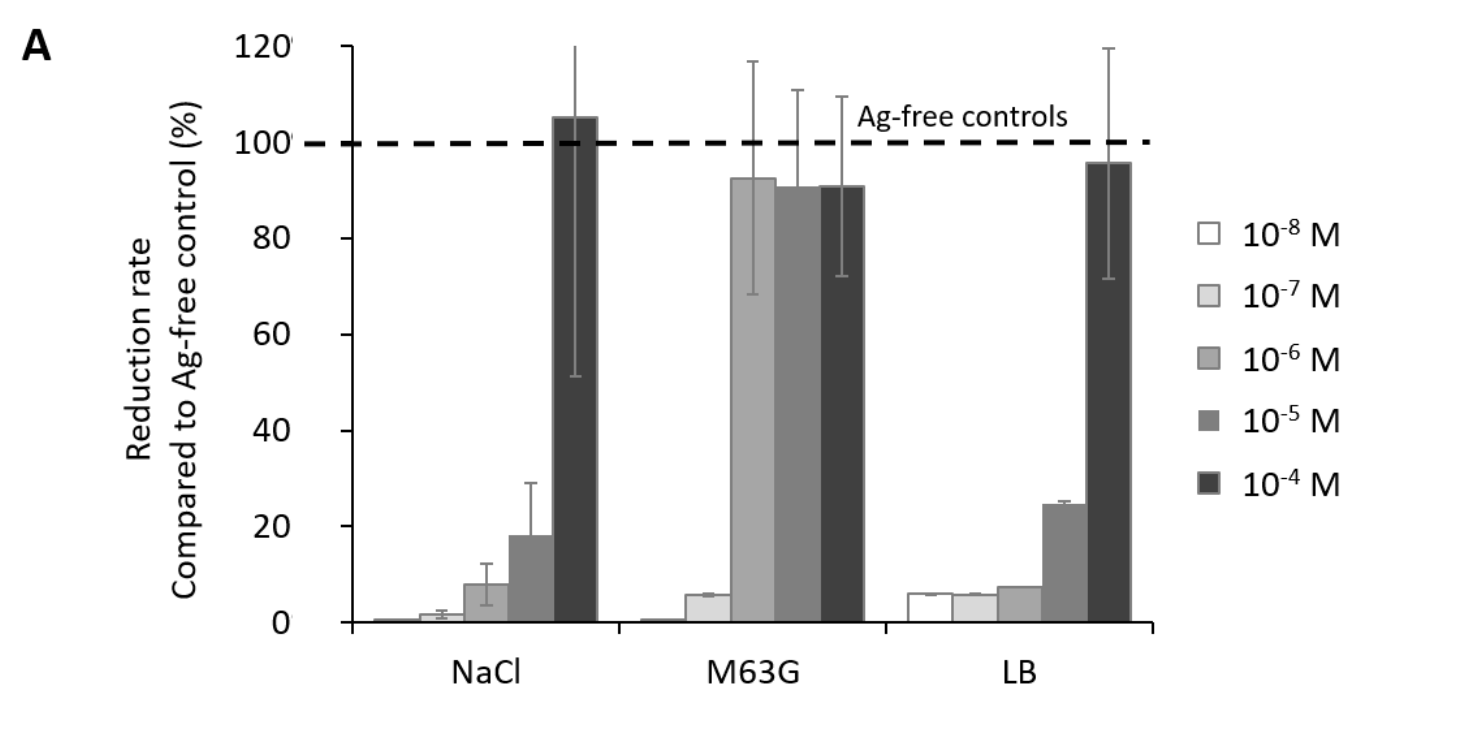


B

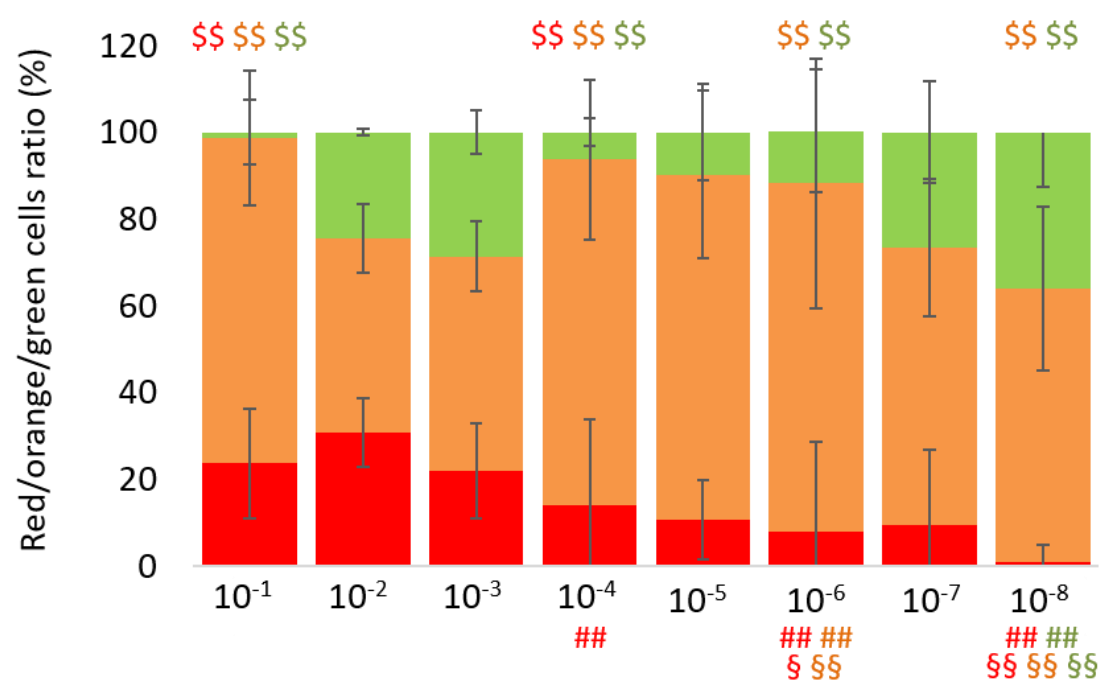

C
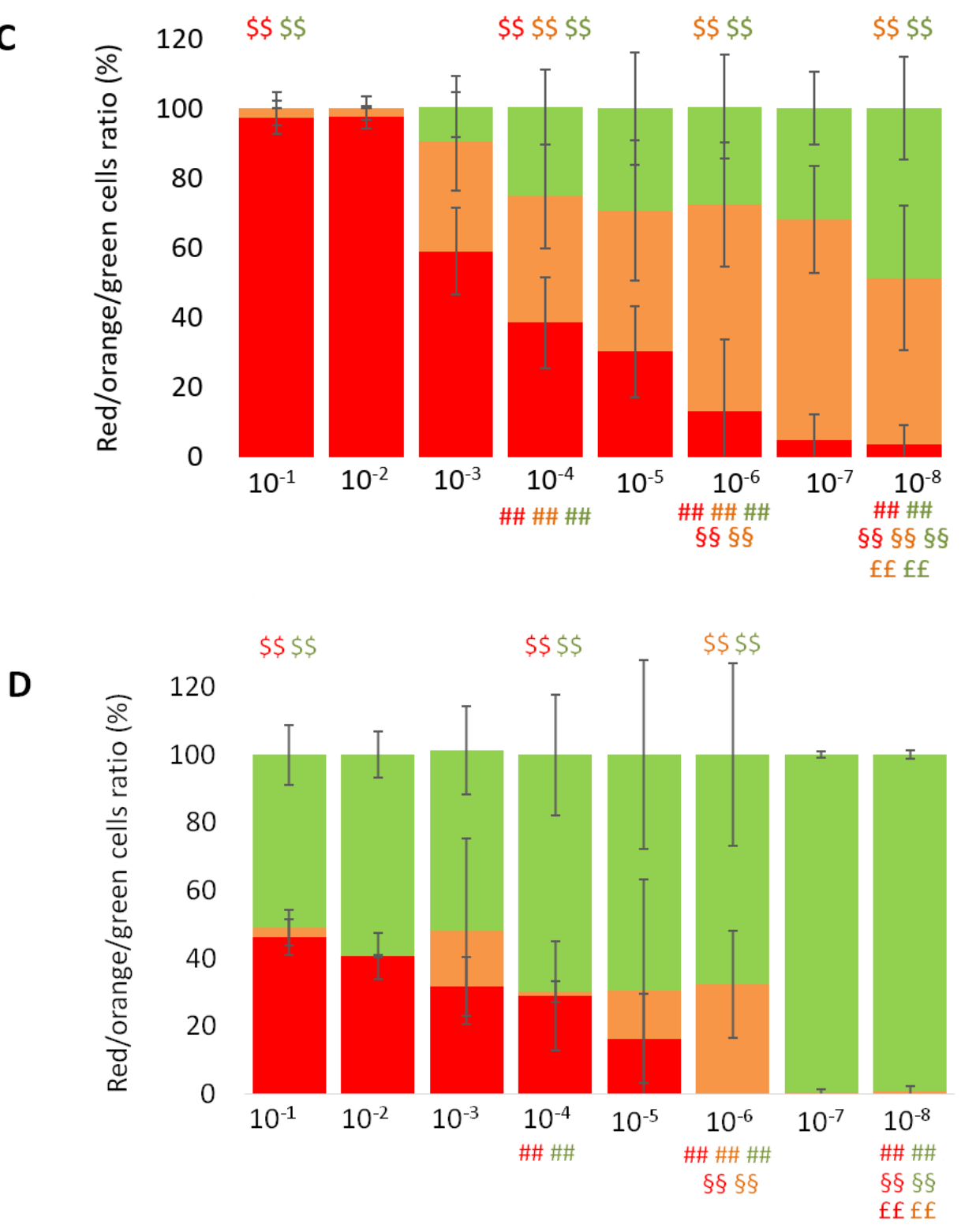


\begin{tabular}{|c|c|c|c|c|}
\hline & $10^{-1} \mathrm{M}$ & $10^{-4} \mathrm{M}$ & $10^{-6} \mathrm{M}$ & $10^{-8} \mathrm{M}$ \\
\hline LB $\quad / M 63 G$ & $* * \quad * *$ & $* * * * * *$ & $* * * * * *$ & $* * * * * *$ \\
\hline LB $\quad / \mathrm{NaCl}$ & $* * * * * *$ & $* * * *$ & $* * * * * *$ & $* * * *$ \\
\hline $\mathrm{M} 63 \mathrm{G} / \mathrm{NaCl}$ & $* * * * * *$ & $* * * * * *$ & $* *$ & $* *$ \\
\hline
\end{tabular}

Fig 7 Impact of silver ions solutions (dilutions from $10^{-1} \mathrm{M}$ to $10^{-8} \mathrm{M}$ ) on E. coli SCC1 population in $\mathrm{NaCl}$, M63G and LB, displayed (A) as the reduction rate after $24 \mathrm{~h}$ of exposition (measured by UV-vis absorption spectroscopy at $600 \mathrm{~nm}$ ) compared to controls $(100 \%)$, and $(B, C, D)$ as ratios of intact, damaged but active and inactive cells after $3 \mathrm{~h}$ of exposition to silver in $\mathrm{NaCl}$ (B), M63G (C), LB (D). Significant differences are displayed by $\$, *$ (displayed in $(E)$ ) and \#, $\S$ and $f$ symbols for comparison to reference, to another medium with the same concentration and to other concentrations in the same medium $\left(10^{-1} \mathrm{M}, 10^{-4} \mathrm{M}\right.$ and $\left.10^{-6} \mathrm{M}\right)$. Green, orange or red color of symbol refers to ratio of intact, damaged but active and inactive cells, respectively

\section{Comparison of antibacterial performances versus compositions of $\mathrm{AgNO}_{3}$ - and $\mathrm{AgNPs-supplemented}$ media.}

Microbiological results demonstrate dramatic differences in the antibacterial efficacy of silver against bacteria according to medium. They are summarized in Fig 8 for a 3.6 10-6 M AgNPs suspension and 10${ }^{6} \mathrm{M}$ and $10^{-1} \mathrm{M} \mathrm{AgNO}_{3}$ solutions (for calculations, see Supplementary Material, Table 3). Efficacy of $\mathrm{AgNO}_{3}$ solutions can be roughly ranged in the order Ag-M63G $>\mathrm{Ag}-\mathrm{NaCl} \sim \mathrm{Ag}$-LB while ranking of AgNPs suspensions is AgNPs-M63G AgNPs-NaCl >> AgNPs-LB.

More specifically, bacteria without any traces of sequelae (i.e., active and without any membrane damage) are more than $50 \%$ after $3 \mathrm{~h}$ in $\mathrm{LB}$ with $10^{-6} \mathrm{M}$ of $\mathrm{Ag}^{+}(67 \%)$ or $3.610^{-6} \mathrm{M}$ of AgNPs (72\%) compared to silver-free medium (Supplementary Material, Table 3). They are about $10 \%$ in $\mathrm{NaCl}$ and M63G for the same $\mathrm{Ag}^{+}$concentration, and even $1 \%$ in the AgNPs suspensions in both media. The concentration of $\mathrm{Ag}^{+}$needs to reach $10^{-2} \mathrm{M}$ (similar results as $10^{-1} \mathrm{M}$ ) to reduce the fraction of unaffected bacteria at less than $10 \%$ in LB and less than $1 \%$ in the others. Based on the unaffected fraction at high $\left(10^{-1} \mathrm{M}\right)$ and at low $\left(10^{-6} \mathrm{M}\right) \mathrm{Ag}^{+}$concentrations, $\mathrm{NaCl}$ and $\mathrm{M} 63 \mathrm{G}$ appear therefore to provide similar favorable surroundings for silver efficacy. However, inactive bacteria were found in a much higher concentration in M63G than in $\mathrm{NaCl}$ after $3 \mathrm{~h}$ of contact. Accordingly, cells were also highly more affected in M63G than in $\mathrm{NaCl}$ after $24 \mathrm{~h}$ of contact with $10^{-6} \mathrm{M} \mathrm{Ag}^{+}$solutions: $100 \%$ of the cells were cultivable in $\mathrm{NaCl}(100 \%$ in LB) whereas less than 1\% were cultivable in M63G. This clearly demonstrates that the silver action is much more inhibited in $\mathrm{NaCl}$ and $\mathrm{LB}$ than in $\mathrm{M} 63 \mathrm{G}$, i.e. the 
experimental ranking of antibacterial effects measured in the $\mathrm{AgNO}_{3}$-supplemented mediais $\mathrm{Ag}$-M63G $>\mathrm{Ag}-\mathrm{NaCl} \sim \mathrm{Ag}-\mathrm{LB}$.

This is attributed to the great difference in the medium's composition regarding Ag-containing compounds formed in these media. They are not equal regarding the antibacterial efficacy. Indeed, availability of $\mathrm{Ag}^{+}$for a further interaction with bacterial cells is lowered in a different way according to the various complexes such as $\mathrm{Ag}_{3} \mathrm{PO}_{4}, \mathrm{AgCl}$ and $\mathrm{AgNPs}$ coated by thiol-containing molecules or polysaccharides. $\mathrm{Ag}^{+}$ions entrapped in $\mathrm{Ag}_{3} \mathrm{PO}_{4}$ complexes $\left(\mathrm{Ks}=1.310^{-18}\right)$ are more prone to be released than those found in $\mathrm{AgCl}$ complexes $\left(\mathrm{K} s=1.810^{-10}\right)$ and coated $\mathrm{AgNPs}\left(\mathrm{K} s \sim 10^{-12}\right.$ for methionine for example) due to the high difference in solubility. Accordingly, $\mathrm{Ag}_{3} \mathrm{PO}_{4}$ complexes can provide significant antibacterial effect (Chudobova et al. 2014; Chudobova et al. 2013). In contrast, $\mathrm{AgCl}$ complexes is certainly harmless for bacteria, and, similarly, embedding of nanoparticles in biomolecule matrix or coating can dramatically reduce their toxicity for bacterial cells (Liu et al. 2010; Swathy et al. 2014). Nevertheless, it should be noticed that some authors also describe an insignificant reduction of $E$. coli growth induced by medium supplementation with $\mathrm{NaCl}$ (Liu et al. 2018) or even disagree on the lower efficacy of $\mathrm{AgCl}$ on $\mathrm{E}$. coli $\mathrm{K} 12$ compared to $\mathrm{Ag}^{+}$(Choi et al. 2008). Thus, $\mathrm{Ag}_{3} \mathrm{PO}_{4}$ and $\mathrm{AgCl}$ cannot be considered as strictly active and inactive against bacterial cells, respectively. However, their high difference in efficacy allows to suggest the following ranking of inhibitory and bactericidal efficiency of the three $\mathrm{Ag}^{+}$-containing media: M63G (> 67\% of active silver) $>>\mathrm{NaCl}(0-16 \%$ of active silver) LB (0$1 \%$ of active silver). This is in complete agreement with the experimental ranking of antibacterial effects measured in the $\mathrm{AgNO}_{3}$-supplemented media, i.e. Ag-M63G $>\mathrm{Ag}-\mathrm{NaCl} \sim \mathrm{Ag}-\mathrm{LB}$.

Interestingly, effects of AgNPs suspensions followed a different ranking, i.e. Ag-M63G Ag-NaCl > AgLB. In addition, AgNPs species reveal more effect on growth inhibitory and bactericidal action than $\mathrm{Ag}^{+}$ solution with similar silver content $\left(3.610^{-6} \mathrm{M}\right.$ and $10^{-6} \mathrm{M}$ respectively) in $\mathrm{NaCl}$ and M63G. This suggests that AgNPs in $\mathrm{NaCl}$ and LB do not act on bacterial cells only through the dissolution of $\mathrm{Ag}^{+}$and their antibacterial effect. An additional effect enhances the $\mathrm{Ag}^{+}$-related antibacterial effect of silver. This effect is probably related to the capacity of AgNPs to enter and accumulate within bacterial cells, which was recently still controversial, but was lately clearly demonstrated by Choi and $\mathrm{Hu}$ (Choi and $\mathrm{Hu} 2008$ ). In contrast, AgNPs species in LB medium fail to provide an antibacterial effect which is as efficient as an $\mathrm{Ag}^{+}$solution with a similar silver content. This is fully consistent with the probable prevention of both the potential uptake of AgNPs by bacterial cells and the AgNPs dissolution into $\mathrm{Ag}^{+}$due to the formation of a coating made of a matrix of biomolecules which was shown to embed AgNPs in LB. 
Finally, our results thus provide (i) a strong argument to assert that toxicity for bacteria of AgNPs is actually a combination of indirect (i.e. dissolution and release of $\mathrm{Ag}^{+}$) and direct (i.e. penetration of AgNPs into cells) actions; (ii) an evidence that effects of $\mathrm{Ag}^{+}$and $\mathrm{AgNPs}$ are both strongly but differently modulated by the medium and its components.

$\mathrm{NaCl}$

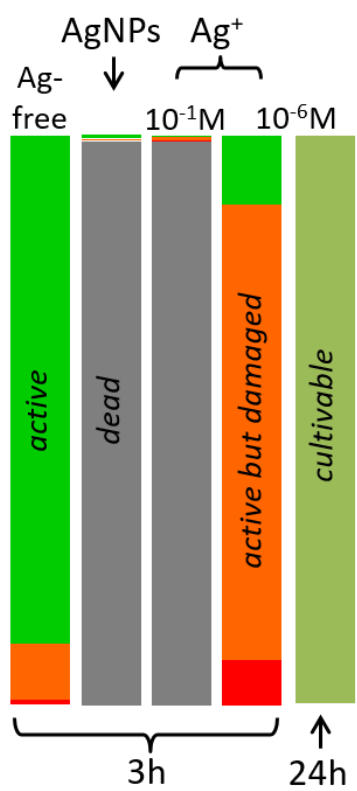

M63G

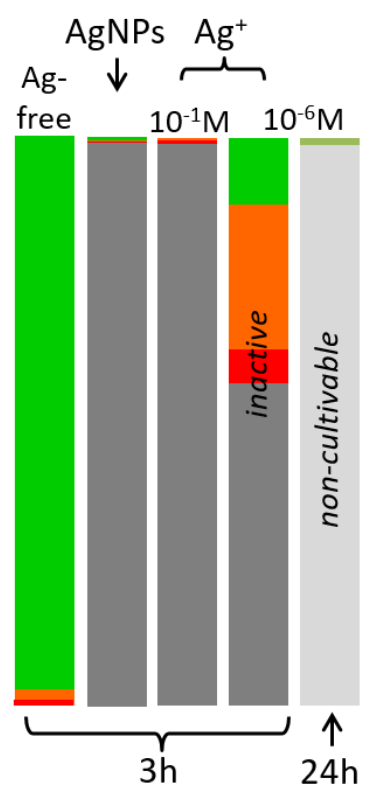

LB

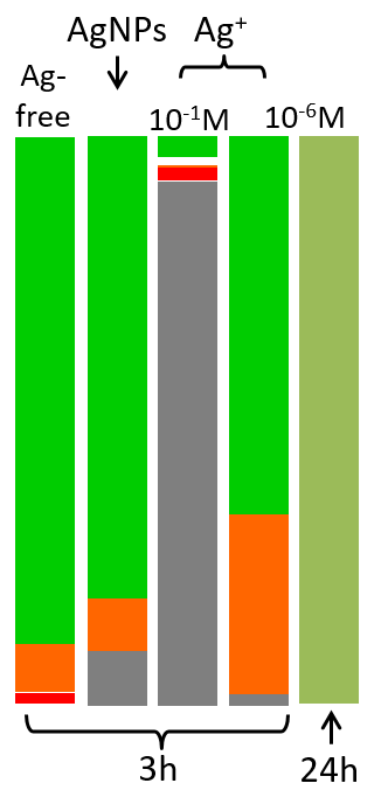

Fig 8 Graphical summary of the impact of $10^{-1} \mathrm{M}$ and $10^{-6} \mathrm{M} \mathrm{Ag}^{+}$solutions and $0.40 \mu \mathrm{g} \mathrm{mL}^{-1}$ (i.e. $3.610^{-}$ $\left.{ }^{6} \mathrm{M}\right)$ AgNPs suspension on the growth of $E$. coli SCC1 populations after $3 \mathrm{~h}$ or $24 \mathrm{~h}$ in $\mathrm{NaCl}, \mathrm{M} 63 \mathrm{G}$ and LB

\section{Conclusion}

This article studied growth inhibition, cell wall degradation and potential for cultivation of $E$. coli bacteria with respect to the biological medium in which they were in contact with silver ions or nanoparticles. It was demonstrated that the medium has a strong influence on the antibacterial performances of both silver nanoparticles and ions, yet to a very different extent. Silver efficacy was maximal in the nutritive minimal medium (M63G) compared to nonnutritive ( $\mathrm{NaCl}$ ) and nutritive rich (LB) media, leading to strong cell damages and growth inhibition for $\mathrm{AgNO}_{3}$ concentrations more than $10^{2}$ times lower than in the two other media. This was related to the solution composition in terms of silver-containing compounds formed according to the biological medium. Especially LB was shown to highly reduce the bioavailability of silver nanoparticles and ions due to the embedding of nanoparticles in an organic matrix and to the formation of very stable $\mathrm{AgCl}$ complex. In contrast, efficacy of AgNPs was similar in $\mathrm{M} 63 \mathrm{G}$ and $\mathrm{NaCl}$ and higher than efficacy of similar amounts of silver ions. Thus, our 
results provide evidence that effects of $\mathrm{Ag}^{+}$and $\mathrm{AgNPs}$ are both strongly but differently modulated by the medium and its components as well as a crucial argument to assert that toxicity for bacteria of AgNPs is actually a combination of indirect (i.e. dissolution and release of $\mathrm{Ag}^{+}$) and direct (i.e. penetration of AgNPs into cells) actions. Furthermore, this work shed light on the dose of silver ions or nanoparticles to be used as bioactive agent according to context of use with regard to the surrounding medium. Even if the investigations were only conducted on three different media, the understanding of the quantitative relation between formation of silver-containing complexes or nanoparticle's embedding by the formation of a coating and the antibacterial performance may allow further forecast of silver nanoparticles and ions fate in other complex media. Results of this study should finally facilitate the difficult decision about the dose of silver to be included in antibacterial materials and coatings with respect to conditions of use and allow comparison between performances of antibacterial systems tested in diverse environments.

\section{References}

Agnihotri S, Mukherji S, Mukherji S (2013) Immobilized silver nanoparticles enhance contact killing and show highest efficacy: elucidation of the mechanism of bactericidal action of silver Nanoscale 5:7328-7340 doi:10.1039/c3nr00024a

Agnihotri S, Mukherji S, Mukherji S (2014) Size-controlled silver nanoparticles synthesized over the range 5-100 nm using the same protocol and their antibacterial efficacy RSC Advances 4:39743983

Audrey C, Patrice G, Bernard B (1999) Physiological changes of Salmonella typhimurium cells under osmotic and starvation conditions by image analysis FEMS Microbiol Lett 179:265-273 doi:doi:10.1111/j.1574-6968.1999.tb08737.x

Cangelosi GA, Meschke JS (2014) Dead or Alive: Molecular Assessment of Microbial Viability Appl Environ Microbiol 80:5884-5891 doi:10.1128/aem.01763-14

Choi O, Deng KK, Kim N-J, Ross L, Surampalli RY, Hu Z (2008) The inhibitory effects of silver nanoparticles, silver ions, and silver chloride colloids on microbial growth Water Res 42:30663074 doi:https://doi.org/10.1016/j.watres.2008.02.021

Choi O, Hu Z (2008) Size Dependent and Reactive Oxygen Species Related Nanosilver Toxicity to Nitrifying Bacteria Environ Sci Technol 42:4583-4588 doi:10.1021/es703238h

Choi Y, Kim H-A, Kim K-W, Lee B-T (2018) Comparative toxicity of silver nanoparticles and silver ions to Escherichia coli Journal of Environmental Sciences 66:50-60 doi:https://doi.org/10.1016/i.jes.2017.04.028 
Chopra I (2007) The increasing use of silver-based products as antimicrobial agents: a useful development or a cause for concern? J Antimicrob Chemother 59:587-590 doi:10.1093/jac/dkm006

Chudobova D et al. (2014) Comparison of the effects of silver phosphate and selenium nanoparticles on Staphylococcus aureus growth reveals potential for selenium particles to prevent infection FEMS Microbiol Lett 351:195-201 doi:doi:10.1111/1574-6968.12353

Chudobova D et al. (2013) Complexes of Silver(I) Ions and Silver Phosphate Nanoparticles with Hyaluronic Acid and/or Chitosan as Promising Antimicrobial Agents for Vascular Grafts Int J Mol Sci 14:13592-13614 doi:10.3390/ijms140713592

Delmée M, Mertz G, Bardon J, Marguier A, Ploux L, Roucoules V, Ruch D (2017) Laser Ablation of Silver in Liquid Organic Monomer: Influence of Experimental Parameters on the Synthesized Silver Nanoparticles/Graphite Colloids The Journal of Physical Chemistry B doi:10.1021/acs.jpcb.7b05409

Durán N, Durán M, de Jesus MB, Seabra AB, Fávaro WJ, Nakazato G (2016) Silver nanoparticles: A new view on mechanistic aspects on antimicrobial activity Nanomedicine: Nanotechnology, Biology and Medicine 12:789-799 doi:https://doi.org/10.1016/i.nano.2015.11.016

Feng QL, Wu J, Chen GQ, Cui FZ, Kim TN, Kim JO (2000) A mechanistic study of the antibacterial effect of silver ions on Escherichia coli and Staphylococcus aureus Journal of Biomedical Material Research A 52:662-668

Fraser JA, Kemp S, Young L, Ross M, Prach M, Hutchison GR, Malone E (2018) Silver nanoparticles promote the emergence of heterogeneic human neutrophil sub-populations Scientific Reports 8:7506 doi:10.1038/s41598-018-25854-2

Gliga AR, Di Bucchianico S, Lindvall J, Fadeel B, Karlsson HL (2018) RNA-sequencing reveals long-term effects of silver nanoparticles on human lung cells Scientific Reports 8:6668 doi:10.1038/s41598-018-25085-5

Gražulis S et al. (2009) Crystallography Open Database - an open-access collection of crystal structures J Appl Crystallogr 42:726-729 doi:10.1107/s0021889809016690

Hogstrand C, Wood CM (1998) Toward a better understanding of the bioavailability, physiology, and toxicity of silver in fish: Implications for water quality criteria Environ Toxicol Chem 17:547-561 Ip M, Lui SL, Chau SSL, Lung I, Burd A (2006) The prevalence of resistance to silver in a Burns unit J Hosp Infect 63:342-344 doi:https://doi.org/10.1016/j.jhin.2006.02.005

ISO 13320:2009 - Particle size analysis -- Laser diffraction methods.

ISO 22412:2017 Particle size analysis -- Dynamic light scattering (DLS). 
Ivask A et al. (2014a) Toxicity Mechanisms in Escherichia coli Vary for Silver Nanoparticles and Differ from Ionic Silver ACS Nano 8:374-386 doi:10.1021/nn4044047

Ivask A et al. (2014b) Size-Dependent Toxicity of Silver Nanoparticles to Bacteria, Yeast, Algae, Crustaceans and Mammalian Cells <italic>In Vitro</italic> PLoS One 9:e102108 doi:10.1371/journal.pone.0102108

Jakobsen L, Andersen AS, Friis-Møller A, Jørgensen B, Krogfelt KA, Frimodt-Møller N (2011) Silver resistance: an alarming public health concern? Int J Antimicrob Agents 38:454-455 doi:https://doi.org/10.1016/i.ijantimicag.2011.07.005

Jung WK, Koo HC, Kim KW, Shin S, Kim SH, Park YH (2008) Antibacterial Activity and Mechanism of Action of the Silver Ion in Staphylococcus aureus and Escherichia coli Appl Environ Microbiol 74:2171-2178 doi:10.1128/aem.02001-07

Jyoti K, Baunthiyal M, Singh A (2016) Characterization of silver nanoparticles synthesized using Urtica dioica Linn. leaves and their synergistic effects with antibiotics Journal of Radiation Research and Applied Sciences 9:217-227 doi:https://doi.org/10.1016/i.jrras.2015.10.002

Kędziora A, Speruda M, Krzyżewska E, Rybka J, Łukowiak A, Bugla-Płoskońska G (2018) Similarities and Differences between Silver lons and Silver in Nanoforms as Antibacterial Agents Int J Mol Sci 19:444

Khan U et al. (2018) Thiamine-functionalized silver nanoparticles for the highly selective and sensitive colorimetric detection of $\mathrm{Hg} 2+$ ions New J Chem 42:528-534 doi:10.1039/c7nj03382f

Knetsch MLW, Koole LH (2011) New Strategies in the Development of Antimicrobial Coatings: The Example of Increasing Usage of Silver and Silver Nanoparticles Polymers 3:340-366

Le Ouay B, Stellacci F (2015) Antibacterial activity of silver nanoparticles: A surface science insight Nano Today 10:339-354 doi:https://doi.org/10.1016/j.nantod.2015.04.002

Li W-R, Sun T-L, Zhou S-L, Ma Y-K, Shi Q-S, Xie X-B, Huang X-M (2017) A comparative analysis of antibacterial activity, dynamics, and effects of silver ions and silver nanoparticles against four bacterial strains vol 123. doi:10.1016/j.ibiod.2017.07.015

Li X-Z, Nikaido H, Williams KE (1997) Silver-Resistant Mutants of Escherichia coli Display Active Efflux of Ag1 and Are Deficient in Porins J Bacteriol 179:6127-6132

Liu J, Sonshine DA, Shervani S, Hurt RH (2010) Controlled Release of Biologically Active Silver from Nanosilver Surfaces ACS Nano 4:6903-6913 doi:10.1021/nn102272n

Liu $\mathrm{M}$ et al. (2018) $\mathrm{NaCl}$ : for the safer in vivo use of antibacterial silver based nanoparticles Int J Nanomedicine 13:1737-1748 doi:10.2147/IJN.S153168

Liu X, Ferenci T (1998) Regulation of Porin-Mediated Outer Membrane Permeability by Nutrient Limitation in Escherichia coli J Bacteriol 180:3917-3922 
Lok C-N et al. (2007) Silver nanoparticles: partial oxidation and antibacterial activities JBIC J Biol Inorg Chem 12:527-534 doi:10.1007/s00775-007-0208-z

Long Y-M, Hu L-G, Yan X-T, Zhao X-C, Zhou Q-F, Cai Y, Jiang G-B (2017) Surface ligand controls silver ion release of nanosilver and its antibacterial activity against Escherichia coli Int J Nanomedicine 12:3193-3206 doi:10.2147/ijn.s132327

MacGregor L, group Ew (2012) Appropriate use of silver dressings in wounds. An expert working group consensus. Wounds International, London

Marchioni M et al. (2018a) Insights into polythiol-assisted AgNP dissolution induced by bio-relevant molecules Environmental Science Nano 5:1911-1920

Marchioni M, Jouneau P-H, Chevallet M, Michaud-Soret I, Deniaud A (2018b) Silver nanoparticle fate in mammals: Bridging in vitro and in vivo studies Coord Chem Rev 364:118-136

Miao H, Ratnasingam S, Pu CS, Desai MM, Sze CC (2009) Dual fluorescence system for flow cytometric analysis of Escherichia coli transcriptional response in multi-species context $\mathrm{J}$ Microbiol Methods 76:109-119

Mogensen KB, Kneipp K (2014) Size-Dependent Shifts of Plasmon Resonance in Silver Nanoparticle Films Using Controlled Dissolution: Monitoring the Onset of Surface Screening Effects The Journal of Physical Chemistry C 118:28075-28083 doi:10.1021/jp505632n

Navolotskaya DV, Toh HS, Batchelor-McAuley C, Compton RG (2015) Voltammetric Study of the Influence of Various Phosphate Anions on Silver Nanoparticle Oxidation ChemistryOpen 4:595599 doi:10.1002/open.201500100

Oliver JD (2005) The Viable but Nonculturable State in Bacteria Journal of Microbiology 43:93-100

Palza H (2015) Antimicrobial Polymers with Metal Nanoparticles Int J Mol Sci 16:2099-2116 doi:10.3390/ijms16012099

Pathak SP, Gopal K (2012) Evaluation of bactericidal efficacy of silver ions on Escherichia coli for drinking water disinfection Environmental Science and Pollution Research 19:2285-2290 doi:10.1007/s11356-011-0735-6

Peterson MSM, Bouwman J, Chen A, Deutsch M (2007) Inorganic metallodielectric materials fabricated using two single-step methods based on the Tollen's process J Colloid Interface Sci 306:41-49 doi:https://doi.org/10.1016/i.jcis.2006.10.013

Pettegrew C, Dong Z, Muhi MZ, Pease S, Mottaleb MA, Islam MR (2014) Silver Nanoparticle Synthesis Using Monosaccharides and Their Growth Inhibitory Activity against Gram-Negative and Positive Bacteria ISRN Nanotechnology 2014:8 doi:10.1155/2014/480284

Rasband W, U. S. National Institutes of Health, Bethesda, Maryland, USA (1997) ImageJ. 
Ratte HT (1999) Bioaccumulation and toxicity of silver compounds: A review Environ Toxicol Chem 18:89-108 doi:doi:10.1002/etc.5620180112

Raveendran P, Fu J, Wallen SL (2003) Completely "Green" Synthesis and Stabilization of Metal Nanoparticles J Am Chem Soc 125:13940-13941 doi:10.1021/ja029267j

Scherrer B (2007) Biostatistique vol 1. Gaëtan Morin éditeur - Les Editions de la Chenelière inc.,

Sedlak RH et al. (2012) Engineered Escherichia coli Silver-Binding Periplasmic Protein That Promotes Silver Tolerance Appl Environ Microbiol:2289-2296

Siddiqi KS, Husen A, Rao RAK (2018) A review on biosynthesis of silver nanoparticles and their biocidal properties J Nanobiotechnol 16:14 doi:10.1186/s12951-018-0334-5

Silver S, Phung LT, Silver G (2006) Silver as biocides in burn and wound dressings and bacterial resistance to silver compounds J Ind Microbiol Biotechnol 33:627-634

Slavin YN, Asnis J, Häfeli UO, Bach H (2017) Metal nanoparticles: understanding the mechanisms behind antibacterial activity J Nanobiotechnol 15:65 doi:10.1186/s12951-017-0308-z

Sütterlin S, Dahlö M, Tellgren-Roth C, Schaal W, Melhus Å (2017) High frequency of silver resistance genes in invasive isolates of Enterobacter and Klebsiella species J Hosp Infect 96:256-261 doi:https://doi.org/10.1016/i.jhin.2017.04.017

Swathy JR, Sankar MU, Chaudhary A, Aigal S, Anshup, Pradeep T (2014) Antimicrobial silver: An unprecedented anion effect Scientific Reports 4:7161 doi:10.1038/srep07161

Vazquez-Muñoz R, Borrego B, Juárez-Moreno K, García-García M, Mota Morales JD, Bogdanchikova N, Huerta-Saquero A (2017) Toxicity of silver nanoparticles in biological systems: Does the complexity of biological systems matter? Toxicol Lett 276:11-20 doi:https://doi.org/10.1016/j.toxlet.2017.05.007

Vidal O, Longin R, Prigent-Combaret C, Dorel C, Hooreman M, Lejeune P (1998) Isolation of an Escherichia coli K-12 mutant strain able to form biofilms on inert surfaces: involvement of a new ompR allele that increases curli expression J Bacteriol 180:2442-2449

Yuting G, J. SH, Gerd H, Matthias S, Hauke H, Y. WL, Susann M (2017) Heterogenic response of prokaryotes toward silver nanoparticles and ions is facilitated by phenotypes and attachment of silver aggregates to cell surfaces Cytometry A 91:775-784 doi:doi:10.1002/cyto.a.23055 